\title{
POLICY-INDUCED INTERNAL MIGRATION: AN EMPIRICAL INVESTIGATION OF THE CANADIAN CASE
}

\author{
KATHLEEN M. DAY \\ STANLEY L. WINER
}

CESIFO WORKING PAPER NO. 1605

CATEgORY 1: Public FinANCE

NOVEMBER 2005

An electronic version of the paper may be downloaded

- from the SSRN website:

www.SSRN.com

- from the CESifo website:

www.CESifo-group.de 


\title{
POLICY-INDUCED INTERNAL MigRATION: AN EMPIRICAL INVESTIGATION OF THE CANADIAN CASE
}

\begin{abstract}
We investigate the influence of public policy on interprovincial migration in Canada using new aggregated migration data for 1974-1996, the longest period studied so far. We consider the consequences of regional variation in a variety of policies, and also investigate the effects of certain extraordinary events in Quebec and in the Atlantic provinces. The results indicate that while the changing bias in the unemployment insurance system may have induced some people to move to the relatively high unemployment Atlantic region, the resulting flows are likely too small to have altered regional unemployment rates. In contrast, political events in Quebec in the 1970's and the closing of the cod fishery in 1992 appear to be associated with large changes in migration patterns.
\end{abstract}

JEL Code: H0, H7, J41, J65, R23, R58.

Keywords: migration, regional disparity, public policy, unemployment insurance, conditional logit, taxation data.

\author{
Kathleen M. Day \\ Department of Economics \\ University of Ottawa \\ 200 Wilbrod Street, P.O. Box 450, Stn A \\ Ottawa, Ontario, K1N 6N5 \\ Canada \\ kmday@uottawa.ca
}

\author{
Stanley L. Winer \\ Carleton University \\ 1125 Colonel By Drive \\ Ottawa, K1S $5 B 6$ \\ Canada \\ stan_winer@carleton.ca
}

The work on which this paper is based was financed by a research grant from Human Resources Development Canada, and by services-in-kind from Statistics Canada under the Visiting Research Fellowship program. We are indebted to Jean-Pierre Voyer, Louis Grignon, Marcel Bédard, Patrick Hayes and Anne Tweddle at HRDC, and to Garnett Picot, Richard Dupuy, Len Landry, Shawna Brown, Lise Champagne, Dan Finnerty, Michel Girard, Pat Grainger, Mark Levesque, Brian Murphy, Ronald Rioux, Abe Tarasovsky and Karen Wilson at Statistics Canada. We also want to thank John Cragg, Jim Feehan, Lars Feld, Ross Finnie, Gebhard Kirchgässner, Pierre Lefebvre, Tim Sargent, and Francois Vaillancourt for helpful comments and assistance with various aspects of the project. Helpful comments were also provided by two anonymous referees, editors Michael Smart and John Wilson, and participants in seminars at HRDC, Carleton University, the University of St.Gallen and at the 58th IIPF Congress in Helsinki. Programming was provided by Manohar Surkund, and research assistance by Michael Francis, Jafar Khondaker, and Richard Levesque. The authors are responsible for any errors and omissions that may have crept into the paper. 


\section{Introduction}

Public policies that support people in relatively depressed regions exist in many countries. It is often argued that one of the major costs of such policies stems from the incentives they create for people to move to, or remain in places where they are less productive. ${ }^{1}$ For example, in Canada the existence of an unemployment insurance system that is substantially more generous (after 1971) towards people who live in regions with above average unemployment rates sustains interregional differences in the portion of an individual's comprehensive income that originates in the public sector. Since individuals base their location decisions on a comparison of comprehensive incomes, and not just on a comparison of their earned incomes, it is argued that such regional differentials in comprehensive incomes lead to a misallocation of labour, thereby reducing average earned income and sustaining regional disparity in the country as a whole.

The argument of course depends crucially on the strength of the influence of public policy on interregional migration, a relationship that cannot be taken for granted. Since migration usually involves a substantial fixed cost, personal decisions may not be greatly affected by regional differentials in the public component of comprehensive incomes if those differentials are not 'large'.

In this paper, we study the influence of federal and provincial policies on interprovincial migration in Canada using new aggregate migration data covering the period from 1974 to 1996 that we have constructed from personal income tax files. ${ }^{2}$ (The data are disaggregated by income class, as well as by age and sex, and are discussed below). The Canadian case is a good one for the study of policy-induced migration. For the past five decades at least, regional development has been an important goal of successive federal governments in Canada, while regional disparity has (some would say, as a result) persisted. ${ }^{3}$

1. For an introduction to the extensive literature on regional disparity and public policy, see for example Graham (1964), Courchene (1970, 1978), Boadway and Flatters (1982 a,b) and Usher (1995).

2. The full version of the study on which this paper is based, Day and Winer (2001), utilizes data for 1968 to 1996 : the 68 - 73 data are from a 10\% sample, while the 74 - 96 data are based on the complete tax tapes. Conclusions reached are the same as those reported in this paper. It should be noted that due to problems in linking individual records, it is not practically possible for us to construct panel data for individuals covering the long time period we investigate. That is why Statistics Canada's own panel data derived from tax records, the LAD, begins in 1982 . 3. The persistence of regional disparities over the 1966-1996 period is illustrated in Appendix Figure A1 concerning variation across the Canadian provinces of weekly earnings and unemployment rates, and in Figure A2 which presents coefficients of variation across provinces of several federal and provincial policy variables. Together the 
The model we construct as a basis for our estimating equations includes more policy parameters and variables than appear in previous studies of internal migration in Canada, especially with respect to the way in which unemployment insurance is represented. Since the representation of the public sector necessarily relies in part on aggregate public expenditure data, and the public sector differentiates between individuals to a considerable extent on the basis of income, disaggregation of migration flows by income class is particularly useful in representing the role of the public sector in the estimating equations. Such diasaggregation also allows for the possibility that the migration decisions of lower income individuals are more likely to be affected by unemployment insurance since it is a relatively more important source of comprehensive income for them than for richer people.

The long time period covered by the data - the longest of any study so far - allows us to include periods in the 1970s when there were important changes in some policy parameters, including unemployment insurance. ${ }^{4}$ We consider the consequences for interprovincial migration flows of regional variation in federal unemployment insurance, provincial social assistance, federal and provincial personal income taxes and public spending of different types, and we compare the effects of these policies to the impacts on migration of wages, employment prospects and moving costs.

We also conduct a preliminary investigation of the migration consequences of certain extraordinary political events in the province of Quebec in the mid 1970s and of the closing of the cod fishery on the east coast after 1992. The study of such events, while of interest in its own right, is of added importance in an investigation of policy-induced migration. It is reasonable to suppose that the fixed costs associated with individual migration decisions are substantial. The extraordinary events may create incentives to move that are large relative to these fixed costs of migration, in contrast (perhaps) to the incentives created by the effects of marginal changes in public policy in more normal times.

The empirical literature on policy-induced migration in Canada provides mixed evidence on the

two figures show that policies in Canada exhibit levels of regional dispersion that are comparable to those of wages and unemployment rates, two variables commonly thought to influence migration.

4. This policy variation is illustrated in Appendix Figure A2. 
question at hand. Although there is some empirical evidence that public policy has affected migration patterns to some extent, notably in the work of Courchene (1970), Winer and Gauthier (1982), Shaw (1986) and Day (1992), in the pre-1995 literature on Canada as a whole - reviewed extensively in Day and Winer (1994) - there is no consensus concerning the empirical significance and quantitative importance of the relationship. ${ }^{5}$ More recently, Lin (1995) uses the Labour Market Activity Survey for the 1988-90 period and finds that interprovincial migration does not depend on receipt of unemployment insurance or social assistance. On the other hand, using the Longitudinal Administrative Data (LAD) set based on tax files for 1982-95, Finnie (2000) finds that the receipt of insurance is associated with a significant increase in outmigration of prime-aged men and women (the quantitative importance of the effect is not computed). However, neither of these interesting contributions take the generosity of the unemployment insurance system into account, and there remains the possibility that the insurance dummy variable used acts as a proxy for employment opportunities rather than reflecting the operation of the unemployment insurance system itself. Audas and McDonald (2003), using the Survey of Labour and Income Dynamics for 1993-1999 and a similar treatment of labour market attachment as in Day and Winer (2001), show that the relationship between unemployment insurance and migration depends on the degree of attachment to the labour market. ${ }^{6}$ They find some evidence that receipt of insurance payments inhibits migration of people who are moderately attached to the labour market, and that the tightening of the rules after 1996 may have given marginally attached workers a stronger incentive to leave high unemployment regions. No quantitative magnitudes of these effects are reported.

Considering the literature in Canada as a whole then, it is reasonable to conclude that the empirical importance of policy-induced migration remains to be confirmed.

We proceed as follows. In section two we present an econometric model of the individual migration

5. For a review of selected U.S. and U.K. studies on the Tiebout process and fiscally-induced migration, see Dowding and Biggs (1994).

6. Audas and McDonald include intraprovincial migration in their study, which one cannot do when exploring the much longer time period considered here. On the labour market attachment of frequent unemployment insurance claimants, see also Schwartz et al. (2001). 
decision, the data are discussed in section three, and estimation results are presented in section four. In section five, we discuss a number of policy simulations based on the estimation that explore the effects of regional variation in selected public policies. These simulations are designed to address the difference between the statistical significance of the point estimates, and the economic importance of the migration flows implied by them. Conclusions, limitations of the analysis and suggestions for future research complete the paper.

\section{A model of interprovincial migration flows}

An individual initially living in province $I$ is assumed to choose province $j$ over all other provincial destinations in any year if and only if his or her utility is higher there. Everyone is similarly considered to be a potential interprovincial migrant in every year and, as in the migration literature generally, the move/stay decision is treated as just another (important) margin on which people continually optimize.

This simple framework may be applied in a manner that allows us to focus on how uncertainty about employment prospects in different regions interacts with the unemployment insurance system to affect migration. We assume that for each individual, the number of weeks of work in each possible destination is a discrete random variable that can have four possible values. These four states correspond, in a stylized manner, to important kinks in an individual's annual budget constraint induced by the unemployment

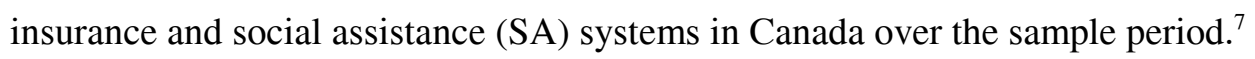

In state 1 , individuals work a total of 50 weeks, leaving them two weeks of leisure time. ${ }^{8}$ In state 2, individuals work a total of $M X Y R$ weeks, where $M X Y R$ is the number of weeks of work such that the individual would be able to spend the remainder of the year collecting insurance benefits. In state 3 , individuals work only $M I N$ weeks, the minimum number of weeks required to qualify for benefits, and they

7. See Phipps (1990) for an illustration of this budget constraint. For an overview of the evolution of the Canadian unemployment insurance system, now called Employment Insurance, see Lin (1998) and Dingledine et al. (1995). 8. The log-linear functional form (described in section 2.1) that we choose for the direct utility function would be undefined in state 1 if this state did not include any leisure time. 
spend the remainder of the year collecting a combination of insurance and social assistance benefits. The unemployment insurance system and the social assistance systems of the provinces thus jointly determine income in state 3 . Finally, in state 4 , it is assumed that individuals spend the entire year on social assistance and do not work.

Given this characterization of labour supply opportunities, the utility maximizing migration decision can be formalized in the following manner. Let $\pi_{j s}$ be the ex ante probability, as seen by the individual, that state $s(s=1, \ldots, 4)$ will occur in province $j$. Assume further that these province-specific aggregate probabilities are independent of any individual's migration decisions, and independent of the region of origin. Then, from the perspective of a person currently resident in province $I$, expected utility in potential destination $j$ is

$$
E U_{i j}=\sum_{s=1}^{4} \pi_{j s} U_{i j s},
$$

where $U_{i j s}$ is the maximum utility that an individual originating in $I$ would enjoy in province $j$ in state $s$. Since the individual chooses the province that yields the highest expected utility, he or she moves to $j$ if

$$
E U_{i j}>E U_{i k}, \quad \forall k \neq j, \quad k=1, \ldots, J
$$

where $J$ is the total number of provinces ( $=10$ in the Canadian case). If $j$ happens to be the individual's province of origin $I$, the individual will not move.

As McFadden (1974) has shown, this model of choice can be converted into an econometric model by assuming that the expected utility of an individual chosen at random from the population is given by

$$
V_{i j}=E U_{i j}+\varepsilon_{i j}
$$

where $\varepsilon_{i j}$ is a random error representing attributes of alternative $j$ that are pertinent to the individual but which the researcher cannot systematically observe. ${ }^{9}$ Then, if the $\varepsilon_{i j}$ are independently and identically distributed 9. Pudney $(1989,112)$ notes that it is implausible to assume that the form of the function $E U_{i j}$ is the same for all 
with a type I extreme value distribution, the probability that an individual in region $I$ will choose to move to $j$ is given by

$$
P_{i j}=\frac{e^{E U_{i j}}}{\sum_{k=1}^{J} e^{E U_{i k}}}
$$

The probability of staying in $I$ rather than moving is $P_{i i}$.

This model emphasizes the role of migration in utility optimization. Indeed, because labour supply is assumed to be fixed in each state of the world, location is the only margin on which individuals are assumed to adjust. ${ }^{10}$ It is also important to note that (4) embodies condition (2) - that migration decisions depend on differences in total expected utility across alternatives. Thus, for example, while some aspects of the UI system may affect the relative price of leisure, as interesting studies of this effect (such as Sargent 1995) have shown, what matters in the present context is how the insurance system alters total expected utility in different locations. For this reason, the representation of the UI system in this paper must be different than in studies designed to measure the effects of this system on the relative price of leisure. ${ }^{11}$

\subsection{Detailed specification of the expected utility and liklihood functions}

As with most applications of the conditional logit model, we choose a functional form for $E U_{i j}$ that is linear in parameters. In particular, assume individuals maximize a Cobb-Douglas utility function:

$$
U_{i j s}=X_{i j s}+\alpha_{2} \ln \left(T-L_{j s}\right)+\alpha_{3}^{\prime} \ln \left(F_{j}\right)+\alpha_{4}^{\prime} \ln \left(A_{j}\right)
$$

where $\alpha_{1}$ and $\alpha_{2}$ are individual coefficients, and $\alpha_{3}{ }^{\prime}$ and $\alpha_{4}{ }^{\prime}$ are vectors of coefficients. As before, the subscript

alternatives. One way of dealing with this problem is to include an additive alternative-specific constant to the function, as we later do.

10. A model in which migration and labor supply decisions and the aggregate state of the labor market in each location are all simultaneously determined would be desirable. Such models have, to our knowledge, not yet been estimated because of their complexity and associated data requirements (but, see Rosenbluth 1996).

11. Other empirical studies of internal migration in which the role of unemployment insurance is dealt with to some extent include Audas and McDonald (2003), Tervo (2000), Antolin and Bover (1997) and Pissarides and Wadsworth (1989). These studies do not model the relevant UI system in the manner or with the detail that we include here. 
$I$ indicates the province of origin, $j$ the province of destination, and $s$ the state of the world. $X$ is real consumption; $T$ is the total time (in weeks) available for work or leisure; $L$ is weeks of work; $F$ is a vector of real fiscal benefits, such as those associated with the provision of education and health care; and $A$ is a vector of locational amenities, including cultural and linguistic factors, that may affect the individual's utility.

In each province and each state of the world, the individual also faces a budget constraint and a labour supply constraint that defines the number of weeks of work available:

$$
\begin{gathered}
q_{j} X_{i j s}+w_{j}\left(T-L_{j s}\right)=w_{j} T+U I_{j s}+S A_{j s}+B_{i s}+T R_{i}-C_{i j}-T A X_{i j s} \\
L_{j s}= \begin{cases}50 & \text { if } s=1 \\
M X Y R_{j} & \text { if } s=2 \\
M I N_{j} & \text { if } s=3 \\
0 & \text { if } s=4 .\end{cases}
\end{gathered}
$$

In the budget constraint, $q$ is the price of consumption goods; $w$ is the individual's wage, which is assumed to be identical in all states of the world; $U I$ is income from unemployment insurance benefits; $S A$ is social assistance income; $B$ is interest and investment income; $T R$ is personal transfers from the public sector other than $U I$ and $S A ; C$ is the sum of the before-tax direct and indirect (foregone wage) monetary costs of moving; and TAX is total federal and provincial income tax. ${ }^{12}$ In the labour supply constraint, $M X Y R$ is the number of weeks of work required to ensure that the individual will receive UI benefits for the remainder of the year, while $M I N$ is the minimum number of weeks of work required to qualify for regular UI benefits. Note that based on specific institutional features of the Canadian case, some components in (6) depend on $I$ and $j$, while others are assumed to depend on either $I$ or $j$ but not both.

12. It is possible to rewrite the budget constraint in terms of the marginal tax rate. While its form has no bearing on estimation, it is convenient to reformulate the budget constraint as a function of the marginal tax rate in order to derive the derivatives of the migration rates $P_{i j}$ with respect to the various components of income. We discuss one such derivative below. See Day and Winer (2001), Appendix E, for the reformulated versions of after-tax income net of moving costs and a more extensive treatment of the role of taxation. 
Three components of income - UI, SA, and $B$ - depend on the state of the world. In the case of $U I$ and $S A$, this is because receipt of these forms of income are contingent on the individual being unemployed. Interest and investment income are assumed to be zero in state 4 because unemployed individuals with a substantial amount of interest and investment income would be deemed ineligible to receive social assistance benefits. Otherwise, $B$ is assumed to depend only on the province of origin.

Maximum utility for each ijs combination is derived by maximizing (5) subject to constraints (6) and (7). The results are substituted into equation (1) to obtain the following expression for expected utility:

$$
\begin{aligned}
E U_{i j} & =\alpha_{1}\left[\pi_{j 1} \ln I N C_{i j 1}+\pi_{j 2} \ln I N C_{i j 2}+\pi_{j 3} \ln I N C_{i j 3}+\pi_{j 4} \ln I N C_{i j 4}\right] \\
& +\alpha_{2}\left[\pi_{j 1} \ln (T-50)+\pi_{j 2} \ln \left(T-M X Y R_{j}\right)+\pi_{j 3} \ln \left(T-M I N_{j}\right)+\pi_{j 4} \ln T\right] \\
& +\alpha_{3}^{\prime} \ln \left(F_{j}\right)+\alpha_{4}^{\prime} \ln \left(A_{j}\right) .
\end{aligned}
$$

where $I N C_{i j s}$ is the income received in province $j$ in state $s$ by an individual originating in province $I .{ }^{13}$

In the case of grouped data, such as we use in this study, a likelihood function can then be constructed using equations (4) and (8) by assuming that all individuals in a particular group are identical. If we define $h$ to be an index of the specific group to which an individual belongs, where $n_{i j h}$ (possibly equal to zero) is the number of individuals in group $h$ going from region $I$ to region $j$, the log-likelihood function for a sample of $H$ groups in $\mathrm{J}$ regions is

$$
\ln L=\sum_{h=1}^{H} \sum_{i=1}^{J} \sum_{j=1}^{J} n_{i j h} \ln P_{i j h}
$$

where $P_{i j h}$ represents the probability of moving from $I$ to $j$, given by equation (4), for individuals in group $h$. In this study groups are defined by income class and year, as well as in some cases by age and sex, as described in detail below. After substitution of the expected utility function (8) into (4), some further amendments described in section 2.2, and measurement of the variables on the right-hand side of (8), discussed extensively in section 3, maximization of (9) provides our estimates of the parameter vector $\boldsymbol{\alpha}^{14}$

13. See the Appendix for the exact definitions of $I N C_{i j s}$ and its components. Note that the consumption good's price, $q_{j}$, appears separately from the income terms in (8) because it is assumed to be the same in all states of the world.

14. If one assumes that $V_{i j}$ in equation (3) is the utility function of a representative individual with average incomes, 
Since (8) has been derived using the direct utility function (5), it is straightforward to predict the signs of the coefficients $\alpha_{j}{ }^{15}$ Consumption and leisure time are both 'goods,' so estimates of both $\alpha_{1}$ and $\alpha_{2}$ in equation (8) are expected to be positive. Similarly, any fiscal variable $F$ or locational amenity $A$ whose estimated coefficient is positive (negative) can be interpreted as providing positive (negative) utility to individuals.

Equation (8) can be used to indicate why the incentive to move embedded in the unemployment insurance system (or in any policy) cannot be captured by a single index variable, as we noted earlier: (8) shows that differences in the probability weighted log-incomes and probability weighted log-leisure times, not in individual policy parameters, are what matter to the utility maximizing individual in the present framework. We examine the nature of these broader measures later.

\subsection{Extensions of the basic model}

The basic model of utility maximization needs to be extended in several ways for empirical application. First, to allow for more risk aversion than the Cobb-Douglas form of (5) implies, we add to equation (8) the probabilities of the less than full employment states. This also allows for the possibility that individuals value employment in and of itself.

Second, we add two variables to reflect non-monetary moving costs that are not incorporated in the variable $C_{i j}$. The distance between the province of origin and the province of destination is added to capture the non-monetary costs of moving that increase with distance, while a dummy variable equal to one if the choice involves a move and zero otherwise is included to account for fixed costs of moving, such as the psychic cost of leaving family and friends behind and re-establishing one's home in a new location, the costs

average wages, etc.; $\mathcal{E}_{i j}$ in equation (3) is the mean over individuals of the random terms in their utility functions; and individuals have independent, identical random utility terms with a Type I extreme value distribution; then one can show that the distribution of the mean random utility term in (3) can be approximated to the first order by a Type I extreme value distribution. In this sense the conditional logit model estimated with aggregate data can be viewed as a first-order approximation to the true aggregate model of migration. See Chapter 2 and Appendix 1 of Day (1989) for further details.

15. Note that while their signs can be predicted, in a conditional logit model the coefficients do not equal the derivatives of the probability of migrating with respect to the independent variables, because of the nonlinearity of equation (4). The effects of changes in the explanatory variables can be explored through simulations, as below, or through the calculation of marginal effects, as in the longer version of this paper, Day and Winer (2001). 
of selling a home, and the costs of finding a new place to live. The inclusion of this dummy variable in the model ensures that the utility associated with staying, $E U_{i i}$, will differ from the expected utility associated with all moves $\left(E U_{i j}, j \neq I\right)$ even if the attributes of all regions are identical. ${ }^{16}$

Third, we added dummy variables to allow a preliminary consideration of two extraordinary events related to the public sector, the effects of which are probably not adequately captured by the other private and public sector variables of the model - the election of a separatist government in Quebec in 1976 and the subsequent introduction of language legislation in 1977, and the closing of the cod fishery on the east coast in 1992. As noted earlier, these extraordinary events may create migration incentives that are substantial relative to fixed costs of moving. The exact definitions of these dummy variables, which distinguish between inflows and outflows, are given in Table 2.

The timing of the dummy representing the events in Quebec corresponds to a pronounced peak in net outflows from Quebec, also identified by Vachon and Vaillancourt (1999). What we are investigating is the extent to which all private and public sector determinants of migration that can be included in our model can account for this unusual episode. The same is the case for the closing of the Cod fishery.

Finally, we must include dummy variables to control for the effects of language and provincespecific amenities. The possibility that the predominance of French in Quebec might deter in-migration to Quebec from other provinces is accounted for by including a dummy variable that is equal to one if the alternative under consideration is a move to Quebec and the province of origin is not Quebec, and zero otherwise. Amenities such as climate, which do not change much over time, are dealt with by including alternative-specific dummy variables for all provinces except British Columbia. ${ }^{17}$

\section{Data}

While an analysis of destination choice based on the income tax microdata would certainly be of interest,

16. Note that this dummy variable does not identify stayers. Rather, it adds an extra term to the utility associated with the staying option for all individuals, whether movers or stayers.

17. One alternative must be excluded to avoid the equivalent of a dummy variable trap. 
the data requirements of such an exercise are formidable. One needs individual-specific data on wages, the probabilities of the four states of the world, and the fiscal benefits that would be received in each possible destination. Since such data are simply not available - at best, microdata sets provide information on some of these variables only for the destination actually selected - we have chosen to work with gross flow data instead, disaggregated by income class, age and sex. ${ }^{18}$ Most results presented in this paper use data disaggregated by income class only. This choice allows us to use provincial fiscal and other aggregates to measure the explanatory variables of the model. ${ }^{19}$ Some key simulations making use of data disaggregated by age and sex as well are also reported in Table 6 below, and further results, consistent with the conclusions reached in the paper, are found in the longer version of this study.

In the remainder of this section we provide a brief description of the migration data and the data used to represent the explanatory variables of the model. Further details regarding the sources and construction of the data are provided in the extensive data appendices of Day and Winer (2001).

\subsection{The new migration data}

The migration data for 1974-1996 are constructed from personal income tax records for the tax years $1973-1996 .{ }^{20}$ For any tax filer, interprovincial migration is assumed to have occurred sometime during the second of two adjacent tax years if the individual reports a different province of residence on December $31^{\text {st }}$ of the second year. All tax filers are included in our migration counts, with the exception of: (I) those younger than 20 or older than 64; (ii) immigrants, emigrants, and persons migrating to or from the northern territories; (iii) persons who died during the tax year; (iv) those with no income from wages and salaries, self-

18. There are disadvantages as well as advantages of using grouped data, including the possibility of aggregation bias. But Grunfeld and Griliches (1960) point out that aggregation may result in gains if specification error is a problem in micro models. Another major advantage is the long time period covered. We also recall here footnote 2 concerning data construction issues.

19. Doing so is equivalent to assuming that the values of the explanatory variables are identical for each individual in a particular income class in a given year who originated in province $I$.

20. Construction of the data used in this study was a substantial project in its own right. The data were also extended backward to 1968 with the help of tapes containing the partial tax records of a $10 \%$ sample of Canadians for the period 1967-1973, but estimation results based on the extended data set are not presented here. For further details, see Day and Winer (2001). Results of estimation over the longer period are consistent with the conclusions reached below. Manohar Surkund's extensive programming was essential to data construction. 
employment, unemployment insurance or social assistance; and (v) full-time students. ${ }^{21}$ These exclusions were designed to restrict the data set to individuals who are attached to the labour market. For each individual remaining in the data set, both the province of origin and destination were recorded for each year from 1974 to 1996 . The tax filers were then grouped into three income classes based on total income as defined by Revenue Canada $\left(T I^{R C}\right):^{22}$

$\begin{array}{ll}\text { Low income: } & 0<T I^{R C} \leq 0.5 \text { median }\left(T I^{R C}\right) \\ \text { Middle income: } & 0.5 \text { median }\left(T I^{R C}\right)<T I^{R C} \leq 1.25 \text { median }\left(T I^{R C}\right) \\ \text { High income: } & T I^{R C}>1.25 \text { median }\left(T I^{R C}\right) .\end{array}$

The age categories used when the data were disaggregated further by age and sex are 20-34, 35-44 and 45-64.

Finally, the number of individuals in each cell of the data set was recorded, with cells being defined by year, province of origin and destination, income class, and age and sex if these characteristics were also employed.

Since these migration data are derived from individual tax records, strict confidentiality conditions apply to their use. Despite the fact that we began with the complete set of tax returns filed in each year, many of the migration cells with an origin and a destination in one of the smaller provinces contain few individuals, and do not meet Statistics Canada's strict conditions for their publication. Rather than work with a publishable data set that contains many censored cells, we employ the uncensored migration data. Statistics Canada has, however, agreed to retain this data for a period of ten years, and to make them available without cost to other researchers interested in confirming the results reported here. ${ }^{23}$

Because we include only tax filers in our migration data, our estimates of migration flows differ from

21. All tax filers under the age of thirty who claimed a tuition deduction of at least about three-quarters of the average university tuition payed in Canada each year in each province were assumed to be students. This rule will not eliminate all students, however, since many transfer the deduction to a parent.

22. In 1995, for example, median total income for all tax filers in our data set is about $\$ 24,142$, or about $62.5 \%$ of the median income for families and unattached individuals reported in Statistics Canada catalogue 13-207. The lower median income in the tax data in part reflects the fact that since families do not file joint tax returns in Canada, the income of each spouse is recorded separately. Median total income in the tax files is consistently lower than median family income, although the ratio of the two varies from year to year.

23. Researchers interested in using these data should contact the Business and Labour Market Analysis Division of Statistics Canada. The conditions for using the data include being sworn in under the Statistics Act, and working with the data on Statistics Canada premises. We are grateful to Garnett Picot and Statistics Canada for making this arrangement. 
the official series published by Statistics Canada. Table 1 below provides an overview of the pattern of migration flows in our data during the sample period. Gross inflows and outflows are small; they rarely exceed two percent of the ex ante population.

Table 1. Selected Sample Migration Rates, All Income Classes, 1974-1996

\begin{tabular}{|c|c|c|c|c|c|c|c|c|c|c|}
\hline & NFLD & PEI & NS & NB & QUE & ONT & MAN & SASK & ALTA & BC \\
\hline \multicolumn{11}{|c|}{ In-migration (percentage of ex ante population) } \\
\hline 1976 & 2.5 & 4.9 & 3.3 & 3.2 & 0.7 & 1.2 & 2.7 & 3.6 & 5.7 & 2.7 \\
\hline 1986 & 1.8 & 3.1 & 2.5 & 2.2 & 0.5 & 1.3 & 2.0 & 2.1 & 2.2 & 2.3 \\
\hline 1996 & 1.6 & 2.8 & 2.3 & 1.7 & 0.4 & 0.7 & 1.5 & 2.1 & 2.8 & 1.9 \\
\hline Mean & 2.2 & 3.9 & 2.9 & 2.5 & 0.5 & 1.0 & 2.1 & 2.5 & 3.6 & 2.9 \\
\hline \multicolumn{11}{|c|}{ Out-migration (percentage of ex ante population) } \\
\hline 1976 & 3.2 & 4.8 & 3.7 & 3.3 & 1.0 & 1.4 & 3.4 & 2.9 & 3.1 & 2.9 \\
\hline 1986 & 3.1 & 3.3 & 2.9 & 2.7 & 0.6 & 0.8 & 2.4 & 2.9 & 3.6 & 1.9 \\
\hline 1996 & 3.5 & 2.4 & 2.3 & 2.0 & 0.5 & 0.8 & 2.0 & 2.3 & 1.9 & 1.5 \\
\hline Mean & 2.9 & 3.8 & 3.0 & 2.7 & 0.7 & 1.1 & 2.8 & 3.0 & 3.0 & 1.9 \\
\hline \multicolumn{11}{|c|}{ Net in-migration (number of individuals) } \\
\hline 1976 & -1136 & 16 & -1164 & -284 & -7381 & -4901 & -2587 & 2033 & 17295 & -1891 \\
\hline 1986 & -2808 & -124 & -1318 & -1716 & -724 & 21945 & -1784 & -3183 & -15246 & 4958 \\
\hline 1996 & -4761 & 225 & -297 & -907 & -5883 & -1957 & -2610 & -1119 & 10272 & 7037 \\
\hline Mean & -1691 & 16 & -323 & -446 & -5638 & -1296 & -3125 & -2164 & 3837 & 10831 \\
\hline \multicolumn{11}{|c|}{ Ex ante sample size (thousands of individuals) } \\
\hline 1976 & 161 & 38 & 277 & 225 & 2165 & 3264 & 372 & 294 & 663 & 924 \\
\hline 1986 & 232 & 52 & 365 & 293 & 2739 & 4116 & 463 & 393 & 1062 & 1163 \\
\hline 1996 & 246 & 61 & 395 & 338 & 3277 & 7627 & 471 & 404 & 1185 & 1566 \\
\hline Mean & 220 & 50 & 349 & 285 & 2698 & 3972 & 436 & 368 & 977 & 1158 \\
\hline
\end{tabular}

Not surprisingly, most migrants originate in the two most populous provinces, Ontario and Quebec.

Over the 1974-1996 period, the provinces that have enjoyed the most in-migration are the relatively highwage provinces of Alberta and British Columbia. Although Ontario, also one of the richest provinces, tended to experience net out-migration on average during the sample period, the average net loss constituted a very small proportion of its population. Newfoundland, the province in which unemployment benefits tended to be highest during the period, experienced net out-migration in all but three years of the sample period despite these benefits. However, at the same time unemployment rates were relatively high and wages were relatively low in Newfoundland, factors which encourage out-migration. 


\subsection{The explanatory variables}

A list of the explanatory variables included in the empirical model, together with their definitions and the expected signs of their coefficients, is provided in Table 2. Note that the first two variables, INCOME and LEISURE, are composite variables that are defined as follows:

$$
\begin{gathered}
I N C O M E_{i j}=\pi_{j 1} \ln I N C_{i j 1}+\pi_{j 2} \ln I N C_{i j 2}+\pi_{j 3} \ln I N C_{i j 3}+\pi_{j 4} \ln I N C_{i j 4}+\ln q_{j} \\
\operatorname{LEISURE}_{i j}=\pi_{j 1} \ln (2)+\pi_{j 2} \ln \left(T-M X Y R_{j}\right)+\pi_{j 3} \ln \left(T-M I N_{j}\right)+\pi_{j 4} \ln (T) .
\end{gathered}
$$

Data on most of the variables required, such as average weekly earnings, interest and investment income, and regional price indexes, were obtained from Statistics Canada sources. The unemployment insurance variables $M I N_{j}, M I N W K S_{j}$, and $M A X Y R_{j}$ are constructed using provincial unemployment rates and the provisions of the Employment Insurance Act, under the assumption that each province constitutes a single insurance region. ${ }^{24} T A X_{i j s}$ is estimated using the actual federal tax schedule and provincial income tax rates, under the assumption that the migrant is single and claims only the personal exemption/tax credit. The last component of income, annual SA income in province $j$, is approximated by the annual social assistance income for a single mother with two children, the only measure which is available on a consistent basis for all provinces throughout the time period studied. ${ }^{25}$ Unfortunately, it is impossible to obtain data on any of these income components that varies with income class. The construction of these data is discussed extensively in Day and Winer (2001) and may be of independent interest.

[Table 2 here]

As it is impossible to obtain a consistent price index that measures differences in the cost of living across provinces for our entire sample period, we use regional city consumer price indices for the major city in each of the ten provinces to represent $q_{j}{ }^{26}$ As in Day (1992) and MacNevin (1984), the components of the vector $F$ in (8) include real per capita consolidated provincial and local government spending on health, education, and other functions, excluding spending on social

24. In fact, the number of UI regions has increased over the years.

25. We are indebted to Pierre Lefevbre for providing us with these data.

26. Létourneau (1992) attempts to measure regional differences in price levels in Canada, but only for 1982-1988. 


\section{Variable name}

LEISURE

Public Expenditure:

HEALTH

EDUCATION

OTHER SPENDING

FEDERAL SPENDING

\section{Moving Costs:}

DSTAY

DISTANCE

Additional Risk Aversion:

Model 1: P2

P3

P4

Model 2: LP234

Extraordinary Events:

PQ

PQ2

FISH

FISH2

Locational Attributes: QUEBEC

NFLD

PEI

NS

NB

QUE

ONT

MAN

SASK

ALTA

\section{Definition}

Sign

expected value of log of leisure time

$\log$ of real per capita provincial and local govt spending on health

$\log$ of real per cap provincial and local govt spending on education

$\log$ of real per cap provincial and local govt spending on other functions, excluding social services and debt service

$\log$ of real per capita current and capital spending by the federal govt

dummy variable equal to 1 if origin = destination, zero otherwise

$\log$ of distance between origin and destination

probability of state 2

probability of state 3

probability of state 4

$\log (\mathrm{P} 2+\mathrm{P} 3+\mathrm{P} 4)$

dummy variable equal to 1 if outflow from Quebec, 1977-80; 0 otherwise

dummy variable equal to 1 if inflow to Quebec, 1977-80; 0 otherwise

dummy variable equal to 1 if outflow from Newfoundland, 1993-96; 0

otherwise

dummy variable equal to 1 if inflow to Newfoundland, 1993-96; 0

otherwise

dummy variable equal to 1 if province of origin is not Quebec and province of destination is Quebec, 0 otherwise dummy variable equal to 1 if choice is Newfoundland, 0 otherwise dummy variable equal to 1 if choice is PEI, 0 otherwise dummy variable equal to 1 if choice is Nova Scotia, 0 otherwise dummy variable equal to 1 if choice is New Brunswick, 0 otherwise dummy variable equal to 1 if choice is Quebec, 0 otherwise dummy variable equal to 1 if choice is Ontario, 0 otherwise dummy variable equal to 1 if choice is Manitoba, 0 otherwise dummy variable equal to 1 if choice is Saskatchewan, 0 otherwise dummy variable equal to 1 if choice is Alberta, 0 otherwise
$-$ ? $?$ ? ? ? ? ? ? ? 
services and debt service, from Statistics Canada's Financial Management System. These data include both current and capital spending by provincial governments. We also include in $F$ per capita total federal current and capital spending in each province (data on federal spending by function are not available by province). All four fiscal variables are deflated using the regional city consumer price index.

Finally, we turn to the measurement of the probabilities of the states of the world. Because the unemployment rate series published by Statistics Canada do not correspond to the four states defined in the model, we estimate the probabilities of the four states using employment data from the Labour Force Survey $\left(n_{E j}\right)$, together with data on the number of individuals receiving UI benefits in each province $\left(n_{U I j}\right)$, the number of social assistance cases in each province $\left(n_{S A j}\right)$, the number of UI recipients with more than twenty qualifying weeks of employment, and the number of UI recipients with less than twenty qualifying weeks of employment. The precise definitions used are given in the Appendix and discussed further in Day and Winer (2001). ${ }^{27}$ One problem with using these data is that while the ex ante probabilities in the model are defined in terms of the distribution of weeks of work across the labour force, $n_{E j}, n_{U I j}$, and $n_{S A j}$ are all measures of the stock of individuals in a particular state at a particular point in time. Data on the distribution of weeks of work by province is limited, necessitating the use of approximations.

Before turning to the estimation results, it is interesting to look at how the migration incentives embedded in the unemployment insurance system are reflected in the variable INCOME (10). Figure 1 shows the probability-weighted income differentials between Ontario and Newfoundland in states 2 and 3 .

\section{[Figure 1 here]}

This figure suggests that until reforms were introduced in the early 1990s, the insurance system was increasingly biased in favour of weakly attached labour market participants who registered for unemployment insurance in Newfoundland. Since the major changes in insurance policy parameters in the 1968-1996 period occurred in 1971, 1974, 1979 and 1994, it can also be inferred from Figure 1 that movements in the probabilities of employment as well as in incomes if unemployed are important in determining migration 27. See the Appendix, equation (A5). Measurement of these probabilities is a substantial undertaking. 
incentives. This is not surprising; incentives to move created by the insurance system depend on both the income received in any location as well as the probability that an individual will need to rely on insurance payments there. In the end, what matters to individuals (in our model) is how the variables INCOME and LEISURE, which take both of these factors into account, are affected by changes in parameters of the insurance system.

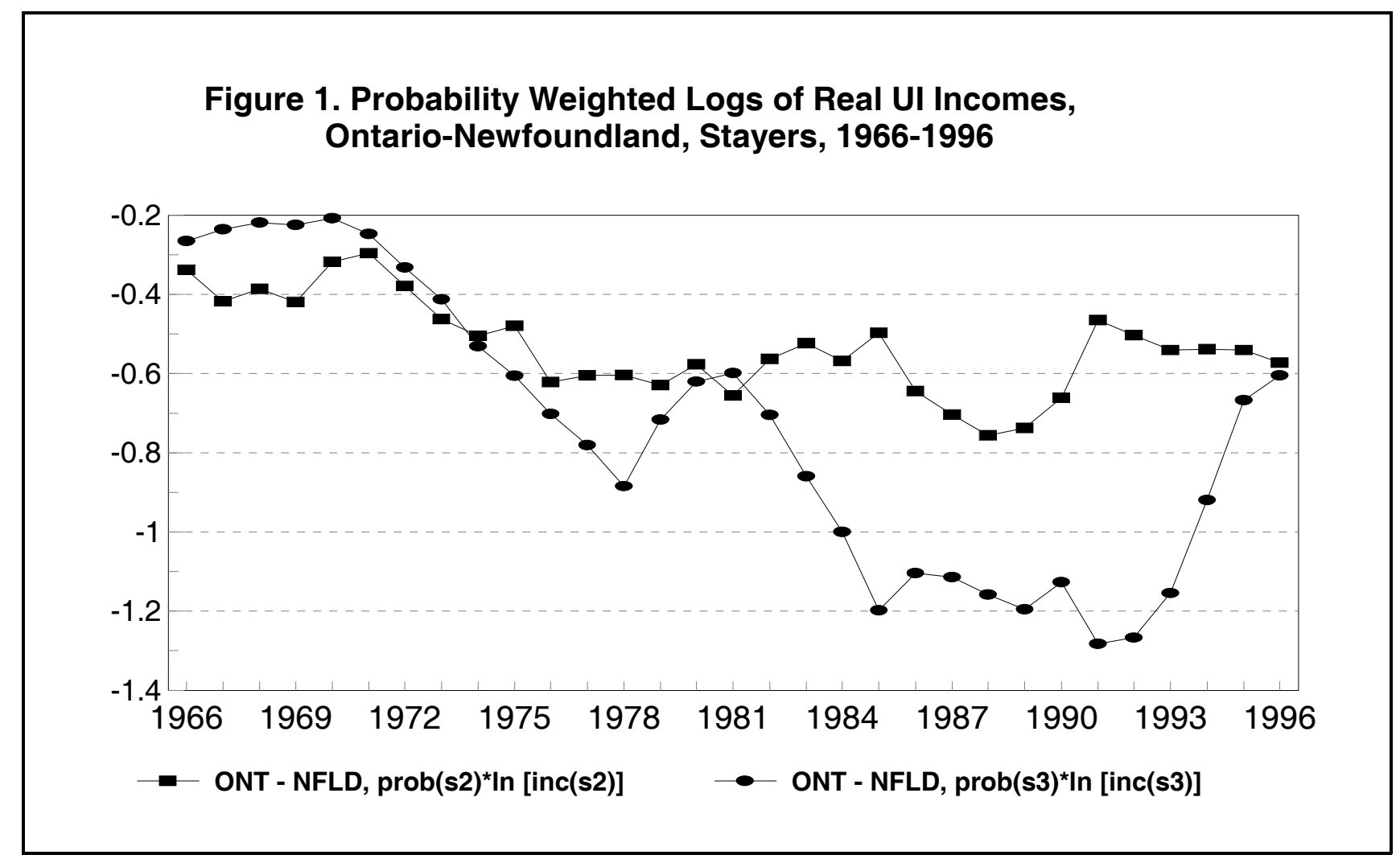

\section{Estimation results}

Maximum likelihood estimates of the parameter vector $\boldsymbol{\alpha}$ for each of three income classes for the period 1974-1996 are presented in Table $3 .^{28}$ Here two versions of the model are provided. As indicated in Table 2 , the two versions differ only in how expected utility (8) is modified to account for additional risk aversion.

28. We recall that the likelihood function used is (9), derived after substitution of (8) as subsequently amended into (4). Estimation was carried out using LIMDEP 7.0. 
In Model 1, the untransformed probabilities of all three unemployment states are allowed to affect expected utility separately. In Model 2, the natural log of the sum of the probabilities of the three unemployment states is used instead.

[Table 3 here]

The overall fit of the model, as measured by McFadden's $\mathrm{R}^{2}$, is quite good for all income classes and both models; all the $\mathrm{R}^{2}$ values exceed 0.9 . However, the correlations between the actual and fitted values of the 100 origin-destination specific migration rates for each income class are often low, ranging from -0.4372 to 0.9002 for Model 1 and -0.7749 to 0.9163 for Model $2 .{ }^{29}$ Thus the model does not do a uniformly good job of explaining many of the origin-destination specific migration rates. Though few if any migration studies actually report such correlations, so that we cannot make comparisons, we suspect they are not uncommon. Correlations between the actual and fitted values of aggregate in-, out-, and net in-migration flows for each province, defined over all possible destinations for each province, are generally higher, especially for the low income class. For example, for out-migration in model 1 they range from 0.4195 to 0.9149 for the low income class.

Turning now to the parameter estimates in Table 3, it can be seen that the values of the coefficients of INCOME, LEISURE and the public expenditure variables are sensitive to the manner in which the probabilities of unemployment are included. The coefficients on INCOME and LEISURE for Model 1 tend to be larger, for each income class, than the corresponding estimates for Model 2. In one case, for the high income class in Model 2, the coefficient on the leisure term is negative and statistically insignificant. ${ }^{30}$

29. The full matrices are available in Day and Winer (2001).

30. Negative coefficients also appear for Models 1 and 2 when the data are disaggregated by age and sex as well as by income class. In Model 1, the estimated coefficient of one or more of the additional risk aversion variables is positive in 19 of 54 cases, especially for female groups. (There are 18 income class-age-sex categories and 3 employment probabilities.) For Model 2, 4 of 18 coefficients on the single variable reflecting employment states are positive. We note that when the unemployment insurance simulations reported below are conducted using these disaggregated models, and the results are then aggregated up, conclusions remain essentially the same as reported in this paper. 
Table 3. Parameter estimates by income class, 1974-1996*

\begin{tabular}{|c|c|c|c|c|c|c|}
\hline \multirow[b]{2}{*}{ Variable } & \multicolumn{3}{|c|}{ Model 1} & \multicolumn{3}{|c|}{ Model 2} \\
\hline & $\begin{array}{c}\text { Low } \\
\text { Income }\end{array}$ & $\begin{array}{l}\text { Middle } \\
\text { Income }\end{array}$ & $\begin{array}{c}\text { High } \\
\text { Income }\end{array}$ & $\begin{array}{c}\text { Low } \\
\text { Income }\end{array}$ & $\begin{array}{l}\text { Middle } \\
\text { Income }\end{array}$ & $\begin{array}{c}\text { High } \\
\text { Income }\end{array}$ \\
\hline \multirow[t]{2}{*}{ INCOME } & 1.806 & 2.391 & 1.507 & 0.748 & 1.200 & 0.416 \\
\hline & (41.79) & (63.93) & $(35.07)$ & (18.35) & (34.23) & (10.29) \\
\hline \multirow[t]{2}{*}{ LEISURE } & 2.832 & 7.105 & 4.887 & 0.571 & 0.904 & -0.010 \\
\hline & (12.61) & (36.29) & (21.10) & (26.87) & $(46.70)$ & $(-0.44)$ \\
\hline \multirow[t]{2}{*}{ HEALTH } & -0.471 & -0.414 & -0.300 & 0.169 & 0.149 & 0.192 \\
\hline & $(-28.24)$ & $(-29.33)$ & $(-18.57)$ & (11.19) & $(11.57)$ & (12.93) \\
\hline \multirow[t]{2}{*}{ EDUCATION } & 0.388 & -0.007 & -0.161 & 0.662 & 0.327 & 0.054 \\
\hline & $(26.35)$ & $(-0.521)$ & $(-10.93)$ & $(45.04)$ & $(25.22)$ & $(3.62)$ \\
\hline \multirow[t]{2}{*}{ OTHER SPENDING } & -0.198 & -0.341 & -0.419 & -0.357 & -0.494 & -0.547 \\
\hline & $(-22.91)$ & $(-45.05)$ & $(-48.78)$ & $(-41.89)$ & $(-66.51)$ & $(-64.72)$ \\
\hline \multirow[t]{2}{*}{ FEDERAL SPENDING } & 0.229 & 0.493 & 0.514 & -0.429 & -0.214 & -0.137 \\
\hline & $(22.95)$ & $(59.61)$ & $(52.36)$ & $(-52.02)$ & $(-31.05)$ & $(-1.66)$ \\
\hline \multirow[t]{2}{*}{ DSTAY } & 1.576 & 1.848 & 1.378 & 1.496 & 1.761 & 1.290 \\
\hline & $(155.60)$ & (207.18) & $(133.47)$ & $(149.42)$ & (199.67) & (126.24) \\
\hline \multirow[t]{2}{*}{ DISTANCE } & -0.502 & -0.504 & -0.599 & -0.517 & -0.521 & -0.616 \\
\hline & $(-349.25)$ & $(-398.90)$ & $(-409.63)$ & $(-365.71)$ & $(-419.18)$ & $(-427.42)$ \\
\hline \multirow[t]{2}{*}{ LOG (P2+P3+P4) } & & & & -0.748 & -0.842 & -0.477 \\
\hline & & & & $(-127.85)$ & $(-158.58)$ & $(-79.98)$ \\
\hline \multirow[t]{2}{*}{$\mathbf{P 2}$} & -28.979 & -42.977 & -30.780 & & & \\
\hline & $(-40.50)$ & $(-69.11)$ & $(-41.82)$ & & & \\
\hline \multirow[t]{2}{*}{$\mathbf{P 3}$} & -13.396 & -26.861 & -21.103 & & & \\
\hline & $(-18.53)$ & $(-42.61)$ & $(-28.25)$ & & & \\
\hline \multirow[t]{2}{*}{ P4 } & -9.890 & -23.780 & -17.150 & & & \\
\hline & $(-13.11)$ & $(-36.09)$ & $(-22.03)$ & & & \\
\hline \multirow[t]{2}{*}{ QUEBEC } & -2.243 & -2.351 & -2.065 & -2.240 & -2.348 & -2.066 \\
\hline & $(-407.27)$ & $(-487.53)$ & $(-399.05)$ & $(-406.51)$ & $(-486.77)$ & $(-399.20)$ \\
\hline \multirow[t]{2}{*}{ PQ } & 0.232 & 0.405 & 0.486 & 0.294 & 0.460 & 0.545 \\
\hline & (29.48) & $(64.73)$ & $(73.27)$ & (37.61) & (74.28) & (83.36) \\
\hline \multirow[t]{2}{*}{ PQ2 } & 0.151 & 0.156 & 0.076 & 0.076 & 0.095 & 0.013 \\
\hline & (15.87) & (19.12) & $(8.39)$ & $(8.08)$ & (11.69) & (1.50) \\
\hline \multirow[t]{2}{*}{ FISH } & 0.105 & -0.142 & -0.267 & 0.003 & -0.291 & -0.361 \\
\hline & (10.47) & $(-13.08)$ & $(-17.97)$ & $(0.316)$ & $(-26.83)$ & $(-24.41)$ \\
\hline FISH2 & -0.883 & -1.168 & -1.084 & -0.790 & -1.030 & -0.995 \\
\hline & $(-60.65)$ & $(-83.23)$ & $(-64.56)$ & $(-54.54)$ & $(-73.62)$ & $(-59.48)$ \\
\hline NFLD & 0.354 & 0.469 & 0.054 & -0.572 & -0.641 & -0.903 \\
\hline & $(27.45)$ & (41.11) & $(-3.87)$ & $(-56.85)$ & $(-71.78)$ & $(-86.85)$ \\
\hline PEI & -0.883 & -0.835 & -1.521 & -0.992 & -1.049 & -1.738 \\
\hline & $(-66.57)$ & $(-73.32)$ & $(-110.37)$ & $(-78.46)$ & $(-97.81)$ & $(-136.26)$ \\
\hline NS & -0.491 & -0.661 & -1.069 & -0.211 & -0.378 & -0.890 \\
\hline & $(-40.99)$ & $(-66.12)$ & $(-90.12)$ & $(-17.93)$ & $(-39.23)$ & $(-75.75)$ \\
\hline NB & -0.052 & -0.041 & 0.539 & -0.335 & -0.428 & -0.842 \\
\hline & $(-5.41)$ & $(-4.97)$ & $(-54.72)$ & $(-37.89)$ & $(-56.57)$ & $(-94.78)$ \\
\hline QUE & 1.577 & 1.897 & 1.505 & 1.319 & 1.554 & 1.274 \\
\hline ONT & $(204.72)$ & $(285.40)$ & (198.91) & (180.53) & $(248.98)$ & $(178.52)$ \\
\hline ONT & -0.252 & -0.342 & -0.263 & 0.120 & 0.050 & 0.039 \\
\hline MAN & $(-41.76)$ & $(-66.31)$ & $(-44.42)$ & (24.06) & (11.57) & $(7.78)$ \\
\hline MAN & -1.046 & -1.177 & -1.377 & -0.721 & -0.839 & -1.138 \\
\hline & $(-156.59)$ & $(-208.97)$ & $(-212.09)$ & $(-112.50)$ & $(-153.21)$ & $(-180.63)$ \\
\hline SASK & -1.136 & -1.083 & -1.212 & -1.010 & -0.971 & -1.127 \\
\hline & $(-176.52)$ & $(-194.70)$ & $(-194.34)$ & $(-159.85)$ & $(-177.33)$ & $(-183.35)$ \\
\hline ALTA & -0.543 & -0.541 & 0.542 & -0.595 & -0.589 & -0.538 \\
\hline & $(-90.62)$ & $(-103.05)$ & $(-91.09)$ & $(-99.59)$ & $(-112.58)$ & $(-91.72)$ \\
\hline
\end{tabular}


The sensitivity of the estimates can be attributed to collinearity between the probabilities of the states of the world, the variable LEISURE, and to a lesser extent, the public expenditure variables and INCOME. Due to the structure of the Canadian unemployment insurance system, both $M I N$ and $M X Y R$ are lower in high unemployment provinces, resulting in a higher value for LEISURE in such provinces. Since the probabilities of the three unemployment states are correlated with the provincial unemployment rates, a correlation between LEISURE and the probabilities of the three states exists. It should be noted, however, that experiments with alternative models indicate that it is important to have the probabilities in the model to allow for aversion to regions where employment prospects are relatively poor. Omission of these variables leads to coefficients on income that are often negative, likely because the INCOME variable then acts to some extent as a proxy for undesirable employment prospects as well as for wages.

The signs of the coefficients on HEALTH, EDUCATION, and FEDERAL SPENDING also differ across the two models, suggesting that collinearity between these variables and economic conditions affects these coefficients as well. We can think of no good reason why people might value additional amounts of publicly provided goods such as health care negatively. Perhaps the fiscal aggregates that we have to use in lieu of better measures of public services received are more highly correlated with the other explanatory variables than the actual benefits received would be. It is also possible that these fiscal aggregates are picking up the influence of other factors not accounted for elsewhere in the model.

Despite the collinearity problem, the coefficient of INCOME is generally positive, suggesting that individuals do prefer regions with higher expected incomes. This result is consistent with other studies of interprovincial migration in Canada. Although there is also a strong correlation between the variables DISTANCE and DSTAY (and for this reason we always change these variables together in simulations), the signs of their coefficients are always consistent with our expectations. The negative coefficient of DISTANCE implies that the costs of migration increase with distance from the point of origin. The positive coefficient of DSTAY, which takes on the value 1 for choices that do not involve a move, implies that there are indeed substantial fixed costs associated with migration away from one's home. The coefficient of QUEBEC always has a negative sign, suggesting that language does form a barrier to in-migration to that 
province. It should be noted that the coefficients of DISTANCE, DSTAY, QUEBEC, and the variables related to extraordinary events are all stable across different specifications of the model.

The positive coefficient of PQ for all models and all income classes suggests that the election of a separatist government and subsequent events in the mid to late 1970 s led to an increase in out-migration from the province; although this accords with much anecdotal evidence, actually estimating this effect in the present context is another matter. One should note that the coefficient of PQ2 is also positive, indicating that inflows to Quebec also increased in the mid-1970s. One conjecture is that this increased inflow consists of former Quebecers returning to their home province.

The signs of the coefficients of PQ and PQ2 may not tell the whole story of the extraordinary events in Quebec, though. If other explanatory variables such as average weekly earnings or the probabilities of the unemployment states also changed, then the effect of the dummy variables on migration flows is likely to represent a lower bound on the total effect. Nonetheless, it is still of interest to examine the magnitude of the effect on migration to and from Quebec by comparing the predicted migration flows when PQ and PQ2 are equal to 1, to the predicted flow when PQ and PQ2 are equal to 0. Both the individual effects of these two variables and their net effect on in-migration to Quebec are presented in Table 4. The impact on inflows to Quebec was greatest for the middle and low income groups, while the impact on outflows was greatest for the middle and higher income groups. Over the 1977-1980 period as a whole, the cumulative effect of the political events captured by the Quebec dummy variables is estimated to be an increase in net out-migration of between 26,000 (Model 1) and 33,000 (Model 2) people. By way of comparison, the actual net outflow from Quebec (in our migration data) during the 4 years after the election of the Parti Quebécois was 50,600 people. $^{31}$

[Table 4 here]

31. We are aware of the possible political economy implications of this result. For some recent theoretical studies that bear on the matter, see for example Glaeser and Shleifer (2005) and Boerner and Ubelmesser (2005). 
Table 4. Effect of Extraordinary Events on Migration To and From Quebec and Newfoundland.

\begin{tabular}{|c|c|c|c|c|c|c|c|c|}
\hline & \multicolumn{8}{|c|}{ Estimated change in inflows and outflows as a result of the event } \\
\hline & \multicolumn{4}{|l|}{ Model 1} & \multicolumn{4}{|l|}{ Model 2} \\
\hline & Low income & $\begin{array}{l}\text { Middle } \\
\text { income }\end{array}$ & $\begin{array}{l}\text { High } \\
\text { income }\end{array}$ & Total & $\begin{array}{l}\text { Low } \\
\text { income }\end{array}$ & $\begin{array}{l}\text { Middle } \\
\text { income }\end{array}$ & $\begin{array}{l}\text { High } \\
\text { income }\end{array}$ & Total \\
\hline \multicolumn{9}{|c|}{ Election of Parti Quebécois: 1977-1980 } \\
\hline In-migration to Quebec & 2049 & 2858 & 1152 & 6059 & 1074 & 1788 & 210 & 3072 \\
\hline Out-migration from Quebec & 4754 & 13340 & 14314 & 32408 & 5844 & 14775 & 15625 & 36244 \\
\hline Net In-migration to Quebec & -2705 & -10482 & -13162 & -26349 & -4770 & -12987 & -15415 & -33172 \\
\hline \multicolumn{9}{|l|}{ Closing of Cod Fishery: 1993-1996 } \\
\hline In-migration to Newfoundland & -7553 & -12457 & -7727 & -27737 & -6411 & -10128 & -6738 & -23277 \\
\hline Out-migration from Newfoundland & 1314 & -1536 & -1580 & -1802 & 41 & -3376 & -2245 & -5580 \\
\hline Net In-migration to Newfoundland & -8867 & -10922 & -6147 & -25936 & -6452 & -6752 & -4493 & -17697 \\
\hline
\end{tabular}


Table 4 also presents estimates of the additional effect of the closing of the cod fishery in 1992 on migration to and from Newfoundland, over and above any effect due to related changes in incomes, unemployment rates or any other explanatory variable in the model. Interestingly, inflows to, rather than outflows from Newfoundland seem to be the most affected, registering large decreases for all three income classes. It is possible that this pattern reflects the effect of the TAGS income subsidy program for fishers instituted when the fishery was closed, as in-migrants were not eligible for benefits under TAGS, but this remains a conjecture. ${ }^{32}$

The total effect of the closing is substantial, although considerably smaller for Model 2 than for Model 1. The Model 1 estimates imply a net loss of about 26,000 people, while the Model 2 estimates imply a net loss of less than 18,000 people. These estimated increases in net outflows of tax filers are greater than the actual net outflow (in our data set) of 14,500. The discrepancy between the actual and predicted outflows may be a prediction error, or it may be that other variables included in the model change in an offsetting manner.

Finally, before turning to the role of unemployment insurance, we note that the pattern of signs on the alternative-specific dummy variables indicates that people are generally moving to the west coast (B.C. is the omitted province), as was suggested by the summary data in Table 1. Perhaps the most interesting finding here is that the coefficient of QUE is positive, while those for all other provinces are generally negative. In other words, after allowing for a general tendency for migration to Quebec to be different from that to other provinces (using the QUEBEC dummy discussed earlier), this positive coefficient suggest that some migrants view Quebec as having some amenities that are more desirable than those of the other provinces.

32. We are grateful to Michael Hatfield of Human Resources Development Canada for this suggestion. 


\section{The effect of eliminating regional variation in the determinants of migration}

Although the coefficient estimates tell us something about the direction of the effects on migration of changes in the explanatory variables, because of the nonlinearity of the estimating equation these coefficients cannot alone tell us anything about the magnitude of those effects. In this paper, simulation is the primary method we use to explore the quantitative importance of the various factors underlying internal migration. The simulations are designed to help us better understand the consequences for migration of the elimination of all regional variation in some key policy variables. ${ }^{33}$ To the best of our knowledge, most studies of internal migration do not similarly investigate the importance of their results.

In order to put the policy simulations into better perspective, we simulate the effects of eliminating regional dispersion in average weekly earnings and the probabilities of the four states of the world. We also consider what happens when we eliminate monetary and nonmonetary moving costs, which in the conditional logit model is more or less equivalent to eliminating regional variation in these costs. ${ }^{34}$ All simulations are carried out for both models, in view of the collinearity issue pointed to earlier, in order to investigate the robustness of the results. Table 5 contains a summary of the assumptions underlying the simulations.

[Table 5 here]

All the simulation results are reported as changes from a base case defined by the fitted values of the model being simulated. Because changes in population flows are easier to comprehend than changes in migration rates, we translate the changes in predicted migration rates into changes in migration flows by multiplying each origin-destination specific migration flow by the appropriate provincial population.

33. In Day and Winer (2001) we provide an extensive discussion of calculated marginal effects of policies, including the effects of changes in tax rates.

34. The mathematical expression for the probability of migrating in the conditional logit model, which is given by equation (4), is such that any term in the linear function $E U_{i j}$ that takes on the same value for all alternatives $j$ will cancel out of the numerator and denominator of the expression. This means that eliminating moving costs, which entails setting the variables DISTANCE and DSTAY to zero, has almost the same effect as equalizing moving costs, since in the latter case the variables DISTANCE and DSTAY would drop out of the equation. The only difference between a simulation in which moving costs are equalized and one in which moving costs are eliminated is that in the former the value of the variable INCOME would be slightly different due to the fact that the monetary costs of moving would be nonzero. 
Table 5. Simulation Assumptions

\begin{tabular}{|c|c|c|}
\hline $\begin{array}{l}\text { Simulation } \\
\text { No. }\end{array}$ & Variable(s) affected & Assumptions \\
\hline 1 & $\begin{array}{l}M I N \text { (minimum qualifying } \\
\text { weeks) }\end{array}$ & $M I N=13$ weeks in all provinces in all years \\
\hline 2 & Regional extended benefits & 2 weeks of benefits for each qualifying week of work in all provinces in all years \\
\hline 3 & $\begin{array}{l}M I N \text { and regional extended } \\
\text { benefits }\end{array}$ & Combination of (1) and (2) \\
\hline 4 & Per capita federal spending & Real per capita federal spending identical in all provinces (model structure makes level of real per capita spending chosen irrelevant) \\
\hline 5 & Per capita education spending & Real per capita education spending identical in all provinces (model structure makes level of real per capita spending chosen irrelevant) \\
\hline 6 & Provincial income tax rates & $\begin{array}{l}\text { Provincial piggyback rate set equal to the nine-province average in all provinces for each year. Quebec treated like provinces that are } \\
\text { signatories to the tax collection agreement with the federal government. }\end{array}$ \\
\hline 7 & Social assistance benefits & Annual social assistance benefits set equal to the ten-province average in all provinces for each year \\
\hline 8 & All policy variables & Combination of (3), (4), (5), (6), and (7) \\
\hline 9 & Average weekly earnings & $\begin{array}{l}\text { Average weekly earnings set equal to Canadian Industrial Composite value in all provinces for each year. Foregone wage costs of moving } \\
\text { adjusted accordingly. }\end{array}$ \\
\hline 10 & $\begin{array}{l}\text { Probabilities of states of the } \\
\text { world }\end{array}$ & $\begin{array}{l}\text { For each province, probabilities computed for the aggregate of the ten provinces for each year were used. UI benefits in each state of the } \\
\text { world re-computed, using actual guidelines, under assumption that unemployment rate equal to Canadian average value in all ten } \\
\text { provinces for each year. }\end{array}$ \\
\hline 11 & Moving costs & All moving costs set equal to zero: $C=D I S T A N C E=D S T A Y$ for all $I$ and $j$ and all years \\
\hline
\end{tabular}


Then the origin-destination specific flows are summed across provinces to obtain the change in net inmigration for each province and income class. ${ }^{35}$ Finally, we report only the average change over the 78-96 period because prior to 1978 , there was no regional variation in $M I N$, a key insurance policy parameter.

It should be noted that the simulations are not dynamic. In each year the same policy change is treated as if it were being introduced that year for the very first time. The average changes reported can thus be viewed as the average impact effect of introducing the policy change. We chose to focus on average impact effects for two reasons: first, the difficulty in explaining year-to-year fluctuations in migration flows; and second, the fact that our model (or other extant models for that matter) does not allow us to predict the effects of migration on determinants such as earnings or employment probabilities.

\subsection{Effects on the volume of migration}

First we consider the effect of eliminating regional differences in the explanatory variables on the volume of interprovincial migration. Table 6 presents the change in the total number of migrants relative to the base case or status quo, in percentage terms, for the eleven different simulations that were carried out using Models 1 and 2, including a simulation, shown in italic font, concerning unemployment insurance using data disaggregated by age and sex as well as by income class, where the disaggregated results have been aggregated up by income class. The change in the volume of migration is computed by summing gross outflows across provinces for each income class.

\section{[Table 6 here]}

A comparison across simulations of the percentage change in the total number of migrants indicates that the role of the probabilities of the states of the world dominates the role of average weekly earnings, by up to an order of magnitude (depending on the model used). All the policy variables considered together play a role that is somewhat larger than that of wages for Model $1(4.82 \%$ vs. $3.33 \%)$, and about $1 / 3$ as much as wages for Model 2. The difference in results between models for this simulation likely stems from the

35. See Day and Winer (2001) for more detailed simulation results, including the impact on total inflows and total outflows for each province. 
Table 6. Effect on Volume of Migration of Elimination of Regional Variation

\begin{tabular}{|c|c|c|c|c|c|c|c|c|}
\hline \multirow[b]{2}{*}{ Variable } & \multicolumn{4}{|c|}{ Model 1} & \multicolumn{4}{|c|}{ Model 2} \\
\hline & $\begin{array}{r}\text { Low } \\
\text { Income }\end{array}$ & $\begin{array}{l}\text { Middle } \\
\text { Income }\end{array}$ & $\begin{array}{r}\text { High } \\
\text { Income }\end{array}$ & Total & $\begin{array}{r}\text { Low } \\
\text { Income }\end{array}$ & $\begin{array}{l}\text { Middle } \\
\text { Income }\end{array}$ & $\begin{array}{r}\text { High } \\
\text { Income }\end{array}$ & Total \\
\hline \multicolumn{9}{|c|}{ Change in number of interprovincial migrants as percentage of base case ${ }^{b}$} \\
\hline MIN & 0.12 & 0.10 & -0.00 & 0.07 & 0.02 & 0.01 & 0.00 & 0.01 \\
\hline Regional extended benefits & 0.28 & 0.39 & 0.09 & 0.26 & 0.04 & 0.02 & 0.00 & 0.02 \\
\hline MIN and regional extended benefits & 0.34 & 0.52 & 1.24 & 0.69 & 0.04 & 0.02 & 0.00 & 0.02 \\
\hline MIN and regional extended benefits ${ }^{c}$ & -0.04 & 0.28 & 0.05 & 0.11 & 0.06 & 0.01 & 0.01 & 0.03 \\
\hline Per capita federal spending & 1.41 & 3.22 & 2.25 & 2.36 & 0.59 & 0.34 & 0.02 & 0.32 \\
\hline Per capita education spending & 0.12 & -0.01 & -0.31 & -0.06 & 0.42 & 0.51 & 0.12 & 0.36 \\
\hline Provincial income tax rates & -0.60 & -0.28 & -0.08 & -0.32 & -0.30 & -0.23 & -0.06 & -0.20 \\
\hline Social assistance benefits & -0.28 & -0.36 & -0.24 & -0.30 & -0.12 & -0.18 & -0.07 & -0.13 \\
\hline All policy variables & 2.83 & 6.57 & 4.65 & 4.82 & 0.72 & 0.31 & 0.05 & 0.35 \\
\hline Average weekly earnings & 2.12 & 4.56 & 3.04 & 3.33 & 0.72 & 1.99 & 0.74 & 1.21 \\
\hline Probabilities of states of the world & 27.44 & 42.33 & 28.89 & 33.54 & 1.58 & 4.46 & 5.38 & 3.86 \\
\hline Moving costs & 3449.48 & 4931.71 & 6463.77 & 4955.07 & $3,447.68$ & $4,977.51$ & $6,462.08$ & $4,971.36$ \\
\hline
\end{tabular}


role of federal spending, which has a bigger percentage impact on mobility for Model 1 (2.36\%) than for Model $2(0.32 \%)$.

Individually, the remaining policy variables, including the unemployment insurance variables, play a much less important role than earnings and probabilities (except for federal spending in Model 1). Provincial tax rates have an effect that, for each income class, is more or less the same for the two models. It is interesting to note that in the case of tax rates, the overall change in the number of migrants is smallest for the high income group.

The effect of eliminating regional differences in qualifying weeks for insurance $(M I N)$ has a uniformly small effect compared to, say, the effect of eliminating regional variation in wages in both models. The volume of migration is still relatively unchanged even when all regional variation is eliminated from the insurance system, a policy change that likely is at the extreme end of feasible reforms. While there are some differences across income classes, in all cases the gross change in the number of migrants is quite small when compared to that for average weekly earnings or for the probabilities of the various employment states. One may note that for Model 1, the effect of eliminating variation in MIN and all regionally extended insurance benefits is even smaller when the age/sex disaggregation is used in addition to income class.

Finally, we note that completely eliminating all moving costs has an enormous effect on the volume of migration, exceeding that of all other simulations by two or three orders of magnitude. This simulation differs in nature from the others, in which regional variation is eliminated, but we provide it for the reader's interest nonetheless. ${ }^{36}$

To further assess the importance of the changes introduced in the simulations, we examine their consequences for unemployment rates at the end of this section.

\subsection{Effects on the pattern of migration}

Even if regional dispersion in policy variables has little effect on the volume of migration, it may

36. Recall that as noted in footnote 33 , in our model eliminating moving costs is similar in effect to eliminating regional variation in moving costs. 
still affect the pattern of migration, or the distribution of the population across regions. Table 7 summarizes the effect of the simulations on the pattern of interprovincial migration, for all income classes taken together. Here and in the following Table 8 only results for Model 1 are shown to conserve space: Model 2 results (found in Day and Winer 2001) show basically the same pattern, and lead to similar conclusions.

In most cases, the signs of the coefficient estimates tell us something about the effect of regional variation on the pattern of migration flows. For example, as long as the coefficient of INCOME is positive, the elimination of regional variation in provincial income tax rates will tend to increase net in-migration to provinces where tax rates are relatively high, and reduce net in-migration to provinces where tax rates are relatively low. Indeed, this is exactly what happens: net in-migration rises for the high-tax provinces of Quebec, Newfoundland, New Brunswick, and Nova Scotia, while net in-migration to all other provinces decreases. Similarly, the elimination of regional variation in average weekly earnings (column (9) of Table 7) reduces net in-migration to the relatively high-wage provinces of Ontario, Alberta, British Columbia, and Quebec, and raises net in-migration to all other provinces.

[Table 7 here]

In other cases, the signs of the coefficient estimates alone are not sufficient to tell us what the outcome of the simulations will be. The two simulations involving the insurance parameter MIN are a case in point. The derivative of $P_{i j}$ with respect to $M I N_{j}$ (see the Appendix and also Appendix G of Day and Winer 2001) implies that an increase in $M I N_{j}$ will have two effects on migration from $I$ to $j$ : first, since individuals must work longer to qualify for unemployment insurance benefits in state 3 , wage income will be higher and social assistance income will be lower. As long as the after-tax wage exceeds average weekly social assistance benefits (recall that individuals in state 3 are assumed to go on social assistance when insurance benefits end), and the coefficient $\alpha_{l}$ is positive, this effect will tend to increase inflows to region or province $j .^{37}$

37. No waiting period for the receipt of social assistance is allowed for in this calculation. It is important to note that we are discussing here changes in different employment states that prospective migrants will take into account before they move. 
Table 7. Effect on the Pattern of Migration of Elimination of Regional Variation: Percentage Change in Net In-Migration, Model 1 Simulation (see list below)

\begin{tabular}{|c|c|c|c|c|c|c|c|c|c|c|c|c|}
\hline Province & 1 & 2 & 3 & $\left(3^{\prime}\right)$ & 4 & 5 & 6 & 7 & 8 & 9 & 10 & 11 \\
\hline NFLD & -35.4 & -50.9 & -69.2 & -10.3 & 26.5 & -2.8 & 22.6 & -0.3 & -80.9 & 9.4 & 1690.7 & 12433.9 \\
\hline PEI & -254.7 & -318.0 & -458.1 & -10.3 & -1710.4 & 21.4 & -26.9 & -17.6 & -2896.4 & 2295.4 & 9267.5 & 172443.3 \\
\hline NS & -17.0 & -138.1 & -128.1 & -26.6 & -2548.7 & 37.5 & 27.8 & -17.0 & -3115.7 & 872.9 & 2560.1 & 96255.5 \\
\hline NB & -184.8 & -394.6 & -414.8 & -74.0 & -676.1 & 90.9 & 136.1 & 57.1 & -1681.2 & 1003.8 & 11489.1 & 142936.9 \\
\hline QUE & -1.2 & -14.0 & -13.5 & -2.2 & 90.3 & -3.6 & 70.3 & 1.7 & 160.5 & -10.1 & 238.8 & -22249.9 \\
\hline ONT & 106.9 & 251.0 & 258.1 & 42.7 & -139.4 & -28.0 & -279.1 & -12.5 & -612.6 & -880.5 & -6586.7 & -169860.5 \\
\hline MAN & 7.0 & 14.8 & 18.2 & 3.2 & -78.9 & 4.5 & -0.1 & -1.2 & -84.4 & 84.3 & -277.8 & 8825.4 \\
\hline SASK & 9.6 & 30.3 & 36.9 & 9.0 & 121.1 & 3.3 & -8.2 & 1.1 & 172.5 & 137.6 & -498.6 & 13426.2 \\
\hline ALTA & 13.7 & 27.3 & 36.2 & 3.8 & 297.9 & -19.0 & -99.1 & 3.5 & 761.0 & -174.2 & -1153.4 & 18972.8 \\
\hline BC & -0.6 & -2.4 & -2.2 & -0.2 & 32.4 & 1.7 & -3.8 & -0.7 & 28.3 & -32.0 & 34.7 & 5468.7 \\
\hline
\end{tabular}
(1) $M I N$
(5) Per capita education spending
(2) Regional extended benefits
(6) Provincial income tax rates
(9) Average weekly earnings
(3) $M I N$ and regional extended benefits
(7) Social assistance benefits
(10) Probabilities of states of the world
(4) Per capita federal spending
(8) All policy variables
(11) Moving costs
(3') MIN and regional extended benefits, age-sex-income class disaggregation 
Second, the individual's leisure time will be lower. If $\alpha_{2}$ is also positive, this effect tends to reduce inflows to province $j$. The larger is $\alpha_{2}$ relative to $\alpha_{1}$, or in other words, the stronger is the individual's preference for leisure relative to consumption, the more likely it is that the net effect will be negative so that on balance, people leave the region where the insurance system becomes less generous.

When regional variation in MIN is eliminated over the 1978-1996 period, MIN rises in the Atlantic provinces, Quebec, and British Columbia, where it previously was lowest. The results in Table 7 show that in these provinces, net in-migration falls as a result of this hypothetical policy change. Net in-migration rises in the remaining provinces, which experience a decrease in MIN. Similar results are obtained when regional extended benefits are eliminated, both alone and in conjunction with the elimination of variation in $M I N .^{38}$ Here the results using the age/sex disaggregation in addition to income are shown in column (3'): the pattern is similar to that using income classes only but magnitudes are smaller.

The elimination of all policy variation - an unlikely policy scenario in a federal country like Canada - has more substantial consequences for the regional distribution of population than the individual policy simulations. In both models, Ontario is a net loser of population in this simulation, while the pattern across the other provinces varies with the model employed. The implication is that regional variation in public policy in the country as a whole over the last two decades has not been accomplished at Ontario's expense.

Finally, to complete the discussion of the effects of policy on the pattern of migration, it is interesting to examine the effect of the elimination of moving costs. As column (11) indicates, the result is to redistribute people away from the two central provinces, Ontario and Quebec, to the periphery of the country. This result does not imply that in the absence of moving costs, Ontario and Quebec are less attractive overall than other provinces; rather it is simply a consequence of the fact that Ontario and Quebec have the largest populations. Consequently, a small increase in the rate of out-migration from either of these provinces leads to a much

38. It should be noted that for the high income group using Model 2, the coefficient of LEISURE is negative, which has the effect of reversing the direction of the effects of eliminating regional variation in MIN and regional extended benefits. But the direction of the aggregate effects for all income classes together, while an order of magnitude larger in Model 1 than in Model 2, is still the same. 
bigger outflow of people than a large change in the rate of out-migration from one of the smaller provinces.

\subsection{An assessment of the consequences of regional variation in policy variables}

A number of authors, in particular Courchene $(1970,1978)$, have suggested that policy-induced migration may exacerbate regional disparities in unemployment rates in Canada by making high-unemployment regions more attractive than they otherwise would be. Similar arguments have been made in other countries. However, to our knowledge, no empirical study has directly examined this issue in Canada.

Because we have modelled migration behaviour and not labour market behaviour, we can only estimate the change in provincial unemployment rates resulting from the simulations reported above if we make some assumptions about the impact of migration on unemployment. Accordingly, we assume that all out-migrants from a province were previously unemployed, while all in-migrants to the province will end up employed. Then the change in in-migration will always equal the change in employment, while the change in out-migration will equal the change in unemployment. This pair of assumptions represents the most favourable outcome possible in terms of the impact effect of migration on unemployment rates.

The results of our calculations of the impact of eliminating regional variation in selected variables on provincial unemployment rates are presented in Table 8 . As in the case of the simulations, only the average unemployment rate for the 1978-1996 period - computed using average employment and average unemployment data for the period for individuals of both sexes aged 20-64 - is presented. The calculations are carried out using the simulation results for Models 1, summed over all income classes, derived from the coefficient estimates in Table $2 .{ }^{39}$ The actual average unemployment rate for each province during the period is also presented.

[Table 8 here]

Setting the moving costs simulation aside for the moment, it can be seen that the effects of all the simulations on average unemployment rates are generally quite small, even for the model shown (1) for which changes in migration flows tend to be largest.

39. Results for Model 2 are found in Day and Winer (2001). 
Table 8. Hypothetical Unemployment Rates Resulting from Elimination of Regional Dispersion, Model 1 (average 1978-1996) ${ }^{\text {a }}$

\begin{tabular}{|c|c|c|c|c|c|c|c|c|c|c|}
\hline Simulation & NFLD & PEI & NS & NB & QUE & ONT & MAN & SASK & ALTA & BC \\
\hline MIN & 16.7 & 13.7 & 11.3 & 12 & 10.8 & 7.4 & 7.2 & 6.4 & 7.4 & 9.6 \\
\hline Regional extended benefits & 16.6 & 13.6 & 11.2 & 11.9 & 10.8 & 7.4 & 7.2 & 6.4 & 7.4 & 9.6 \\
\hline MIN and regional extended benefits & 16.5 & 13.4 & 11.2 & 11.9 & 10.8 & 7.4 & 7.2 & 6.4 & 7.4 & 9.6 \\
\hline MIN and regional extended benefits ${ }^{c}$ & 16.8 & 13.9 & 11.3 & 12 & 10.8 & 7.4 & 7.2 & 6.4 & 7.4 & 9.6 \\
\hline Per capita federal spending & 16.8 & 12.1 & 9.9 & 11.7 & 10.9 & 7.4 & 6.8 & 6.6 & 7.5 & 9.6 \\
\hline Per capita education spending & 16.8 & 13.9 & 11.3 & 12.1 & 10.8 & 7.4 & 7.2 & 6.3 & 7.4 & 9.6 \\
\hline Provincial income tax rates & 16.9 & 13.9 & 11.3 & 12.1 & 10.9 & 7.4 & 7.2 & 6.3 & 7.3 & 9.6 \\
\hline Social assistance benefits & 16.8 & 13.9 & 11.3 & 12.1 & 10.8 & 7.4 & 7.2 & 6.3 & 7.4 & 9.6 \\
\hline All policy variables & 16.4 & 10.6 & 9.5 & 11.3 & 10.9 & 7.3 & 6.8 & 6.7 & 7.7 & 9.6 \\
\hline Average weekly earnings & 16.7 & 15.0 & 11.5 & 12.2 & 10.8 & 7.3 & 7.3 & 6.6 & 7.2 & 9.5 \\
\hline Probabilities of states of the world & 17.1 & 15.4 & 11.3 & 13.1 & 10.9 & 6.5 & 5.6 & 4.2 & 6.3 & 9.5 \\
\hline Moving costs & -37.9 & -8.1 & -56.3 & -47.2 & -82.9 & -87.6 & -46.3 & -40.9 & -52.4 & -39 \\
\hline Actual average unemployment rate ${ }^{b}$ & 16.8 & 13.9 & 11.3 & 12 & 10.8 & 7.4 & 7.2 & 6.3 & 7.4 & 9.6 \\
\hline
\end{tabular}

\section{Notes to Table 8:}

${ }^{a}$ Hypothetical unemployment rates were computed under the assumptions that all out-migrants from a province were unemployed prior to moving, and that all in-migrants would be employed after moving. Total employment and unemployment for both sexes aged 20-64, obtained from CANSIM), were used as the basis for the calculations. For each simulation average employment over the 1978-1996 period was computed as actual average employment plus the change in in-migration, while average unemployment was computed as actual average unemployment less the change in out-migration. The average unemployment rate was then computed as the ratio of average unemployment to the sum of average employment and average unemployment. The calculations were done using the simulation results for Model 1, based on the parameter estimates for income classes for 1974-1996.

${ }^{\mathbf{b}}$ The actual average unemployment rate was constructed using the average annual values of employment and unemployment over the 1978-1996 period. It is very similar in magnitude to the average of annual unemployment rates over this period.

${ }^{c}$ Based on estimates disaggregated by age, sex, and income class. 
The only simulation, other than the elimination of moving costs, that has some impact on average unemployment rates is that in which regional variation in the probabilities of the states of the world is eliminated, with the effect varying across provinces. Of course, the complete elimination of moving costs has a large effect on unemployment rates, as would be expected from a shock of this magnitude. ${ }^{40}$ Finally, it is important to note that the impact on average unemployment rates of the elimination of regional variation in the unemployment insurance system is quite small, and that this is also the case when the age/sex/income class disaggregation is used, as shown in row 4. The Model 1 results lead to changes in unemployment rates only in the four Atlantic provinces, with the largest decrease in unemployment rates being half a percentage point in Prince Edward Island. ${ }^{41}$ It should also be remembered that the policy change introduced - the complete elimination of regional policy variation - is very large, so that half a percentage point is likely to be an upper bound for the effects of marginal policy changes in the insurance system that may occur in the future.

\section{Conclusions and suggestions for further research}

Estimation and simulation using our new data set for 1974-1996 indicates that the prime determinants of interprovincial migration are differentials in earnings, employment prospects and moving costs. The impact of the public policies considered here on the total number of Canadians who make interprovincial moves is small, regardless of which model we employ. Both models predict that the elimination of regional extended benefits and regional differences in qualifying requirements for unemployment insurance would have increased the volume of migration by less than $1 \%$. Even the combined elimination of regional variation in all of the policy variables included in the analysis (unemployment insurance, personal income

40. The unemployment rates for this simulation are actually negative, reflecting the fact that the simulated increase in the volume of out-migration exceeded the actual level of unemployment in all provinces. One interpretation of this result is that the elimination of moving costs would encourage many individuals not currently included in Statistics Canada's measure of the labour force to make interprovincial moves. 41. Under Model 2 (not shown in Table 8), average unemployment rates in all ten provinces are completely unaffected by the elimination of regional variation in unemployment insurance. 
taxes, social assistance and provincial and federal spending) is predicted to raise the volume of migration by at most 5\%, or by less than half a percentage point. These results allow for the relatively greater influence of unemployment insurance on the comprehensive incomes of lower income individuals, and are robust (as far as simulations concerning insurance are concerned) to disaggregation of the data by age and sex in addition to income class.

Hypothetical calculations further suggest that regional differences in policy had little impact on unemployment rates across Canada. One should note that previous studies of fiscally-induced migration have not placed much, if any, emphasis on carrying out such quantitative simulations.

Although regional differences in public policies may not have had an impact on interprovincial migration, our results indicate that some extraordinary policy changes probably did. Events following the election of the separatist Parti Québecois government in Québec in the second half of the 1970s, and the closing of the cod fishery in Atlantic Canada in 1992 appear to have substantially altered interprovincial migration. These results suggest that one must be careful to distinguish between the effects of marginal changes in policies on the one hand, and the effects of large, discrete changes which may swamp the retarding influence of even high fixed moving costs on the other.

If the persistence of regional disparity in Canada is to be attributed to regional policies, then, it appears necessary to focus on the differential effects across regions that (may) result from the existence of income support programs, which are more important to people in poorer regions, as distinct from the effects of marginal changes in such programs. In this respect, one should note that the complete elimination of the system of regional subsidies (via unemployment insurance and other policies) is not a shock that is represented in our data, and the effects of such an extraordinary change cannot be inferred from our results. ${ }^{42}$

Avenues for further research suggested by the paper include work on the effects of extraordinary social events; finding other ways of dealing with collinearity of unemployment insurance and employment

42. It also seems wise to consider alternative explanations in which migration does not play its classical role of equalizing opportunity because of high moving costs. On this point, see also Emery (1999). 
prospects; building models in which both migration and labour market outcomes are endogenous; and uncovering the effect of intergovernmental grants on migration. ${ }^{43}$ To get at the effect of the existence of policies, it may be useful to try a long-run equilibrium approach to policy-induced migration as in Pommerehne, Kirchgässner and Feld (1996), which has not been attempted for Canadian data. Finally, in view of the importance of moving costs, careful attention to the role of such costs in future models will be worthwhile.

43. A full study of grants may require that the measurement of individual benefits from public services be improved so that a model of the effect of grants on provincial decisions may be combined with a model of migration behaviour. 


\section{References}

Antolin, Pablo, and Olympia Bover (1997). "Regional Migration in Spain: The Effect of Personal Characteristics and of Unemployment, Wage and House Price Differentials Using Pooled Cross-sections." Oxford Bulletin of Economics and Statistics 59 (2), 215-235.

Audas, Rick and James Ted McDonald (2003). "Employment Insurance and Geographic Mobility: Evidence from the SLID.” Ottawa: SRDC Working Paper Series 03-03, April.

Boadway, Robin and Frank Flatters (1982a) Equalization in a Federal State: An Economic Analysis (Ottawa: Supply and Services Canada for the Economic Council of Canada).

Boadway, Robin and Frank Flatters (1982b) "Efficiency and Equalization Payments in a Federal System of Government: A Synthesis and Extension of Recent Results," Canadian Journal of Economics 15, 613-33.

Boerner, Kira and Silke Ubelmesser (2005). "Migration and the Welfare State: The Economic Power of the Non-Voter?" CESifo Working Paper 1517, August

Courchene, Thomas J. (1970) "Interprovincial Migration and Economic Adjustment," Canadian Journal of Economics 3, 550-76.

Courchene, Thomas J. (1978) "The Transfer System and Regional Disparities: A Critique of the Status Quo," in Canadian Confederation at the Crossroads: The Search for a Federal Provincial Balance, ed. Michael Walker (Vancouver: The Fraser Institute, 145-86).

Day, Kathleen M. (1989) "Government Policies, Unemployment Rates, and Interprovincial Migration in Canada", unpublished Ph.D. dissertation, University of British Columbia.

Day, Kathleen M. (1992) “Interprovincial migration and local public goods," Canadian Journal of Economics $25,123-44$.

Day, Kathleen M., and Stanley L. Winer (1994) "Internal migration and public policy: An introduction to the issues and a review of empirical research on Canada.,"in Issues in the Taxation of Individuals, ed. Allan Maslove (Toronto: University of Toronto Press, 3-61).

Day, Kathleen M., and Stanley L. Winer (2001) "Interregional Migration and Public Policy in Canada: An Empirical Study," Working Paper W-01-3E, Ottawa: Applied Research Branch, Human Resources Development Canada, July, 294 pages. Available at: www.carleton.ca/ winers.

Dingledine, Gary, John Hunter, and Chris McKillop (1995) The History of Unemployment Insurance. Ottawa: Human Resources Development Canada. Available at: www.hrdc-drhc.gc.ca/aeei/hist/history_of_unemployment_insurance.shtml).

Dowding, Keith, Peter John, and Stephen Biggs (1994) “Tiebout: A Survey of the Empirical Literature," Urban Studies 31 (4/5), 767-797.

Emery, J.C. Herbert (1999) "Some Regions are More Equal than Others: Evidence on the Sources of Regional Income Differentials from the Canadian Labour Market Before 1930." Unpublished, Department of 
Economics, University of Calgary, October. In Papers in Political Economy, Political Economy Research Group, University of Western Ontario, 92-95, 2000.

Finnie, Ross (2000) “Who Moves? A Panel Logit Model Analysis of Inter-provincial Migration in Canada." Research Paper no. 142, Business and Labour Market Analysis Division, Analytical Studies Branch, Statistics Canada, August.

Glaeser, Edward L. and Andrei Shleifer (2005). "The Curley Effect: The Economics of Shaping the Electorate." Journal of Law, Economics and Organization 21(1), 1-20.

Graham, John (1964) "Fiscal Adjustment in a Federal Country," in Inter-Government Fiscal Relationships (Canadian Tax Paper No.40), eds. J. Graham, A. Johnson and J. Andrews (Toronto: Canadian Tax Foundation, 3-34).

Grunfeld, Yehuda, and Zvi Griliches (1960) “Is Aggregation Necessarily Bad?” Review of Economics and Statistics 42 (1), 143-155.

Létourneau, Raynald (1992) "Un indice de prix régional de biens et services comparables au Canada et son application aux disparités de revenu." Document de travail No. 92-2, Ministère des Finances, Ottawa.

Lin, Zhengxi (1995) Interprovincial Labour Mobility in Canada: The Role of Unemployment Insurance and Social Assistance. Ottawa: Human Resources Development Canada.

Lin, Zhengxi (1998) “Employment Insurance in Canada: Recent Trends and Policy Changes,' Canadian Tax Journal 46, 58-76.

MacNevin, Alex S. (1984) "Fiscal Integration and Subcentral Public Sector Inducements to Canadian Interprovincial Migration," unpublished Ph.D. dissertation, McMaster University.

McFadden, Daniel (1974) "Conditional Logit Analysis of Qualitative Choice Behaviour," in Frontiers in Econometrics, ed. P. Zarembka. (New York: Academic Press).

Phipps, Shelley (1990) “Quantity-constrained Household Responses to UI Reform..” Economic Journal 100, $124-40$.

Pissarides, Christopher, and Jonathan Wadsworth (1989) "Unemployment and the Inter-regional Mobility of Labour.” Economic Journal 99 (September), 739-755.

Pommerehne, Werner, Gebhard Kirchgässner and Lars feld (1996). "Tax Harmonization and Tax Competition at State-Local Levels: Lessons from Switzerland," in G. Pola and G. France (eds.) Development in Local Government Finance: Theory and Policy. Edward Elgar, 292-330.

Pudney, Stephen (1989) Modelling Individual Choice: The Econometrics of Corners, Kinks and Holes. (Oxford, UK: Basil Blackwell).

Rosenbluth, Gideon (1996) “Interprovincial Migration and the Efficacy of Provincial Job Creation Policies," Canadian Business Economics 4(2), 22-34. 
Schwartz, S., W. Bancroft, D. Gyarmati and C. Nicholson (2001). "The Frequent Use of Unemplyment Insurance in Canada: The Earnings Supplement Project." Ottawa: Social Research and Demonstration Corporation.

Sargent, Timothy C. (1995) "An Index of Unemployment Insurance Generosity," Working Paper 95-10, Department of Finance, Ottawa, Canada.

Shaw, R. Paul (1986) "Fiscal versus traditional market variables in Canadian migration"' Journal of Political Economy 94, 648-666.

Tervo, Hannu (2000) "Migration and Labour Market Adjustment: Empirical Evidence from Finland 19851990," International Review of Applied Economics 14 (3), 343-360.

Usher, Dan (1995) The Uneasy Case for Equalization Payments. Vancouver: The Fraser Institute.

Vachon, Marc and Francois Vaillancourt (1999) "Interprovincial Mobility in Canada, 1961-1996: Importance and Destination," in H. Lazar and T. McIntosh (eds.). How Canadians Connect (Canada: The State of the Federation 1998/99). Queen's University, Institute on Intergovernmental Relations. McGill-Queen's University Press, 101-122.

Winer, Stanley L. and Denis Gauthier (1982). Internal Migration and Fiscal Structure: An Econometric Study of the Determinants of Interprovincial Migration in Canada. (Ottawa: Economic Council of Canada). 


\section{Appendix \\ 1. The persistence of regional disparity in wages, unemployment rates, and federal government public polices in Canada, 1966 - 1996.}

The persistence of regional disparities over the 1966-1996 period is illustrated in Appendix Figure A1, which presents the unweighted coefficients of variation across the ten Canadian provinces of real average weekly earnings and provincial unemployment rates, two labour market variables commonly believed to influence migration decisions. Figure A2 presents coefficients of variation across provinces of several federal and provincial policy variables - real per capita federal current and net capital spending, maximum weeks of unemployment insurance benefits to which a person with minimum qualifying weeks is entitled, real per capita provincial government spending on health, real per capita provincial spending on education, and real social assistance payments for a single mother with two children. Together the two figures show that public policies in Canada exhibit levels of regional dispersion that are comparable to those of wages and unemployment rates.

Figure A1. Regional Variation in Labour Market Variables

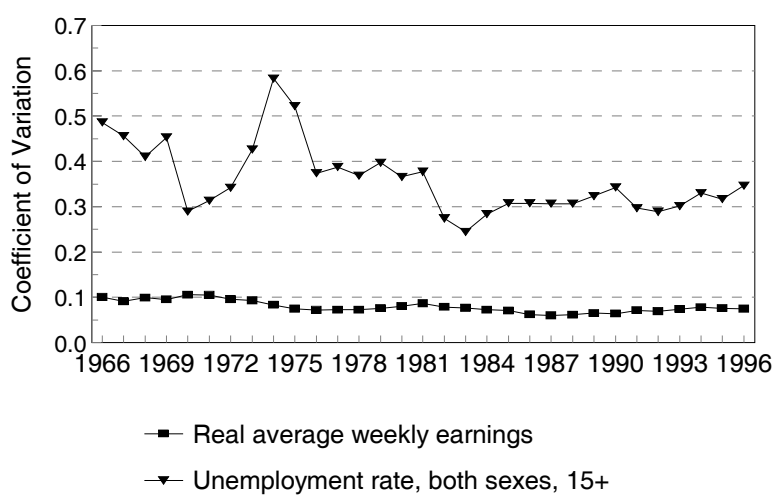

Figure A2. Regional Variation in Government Policies

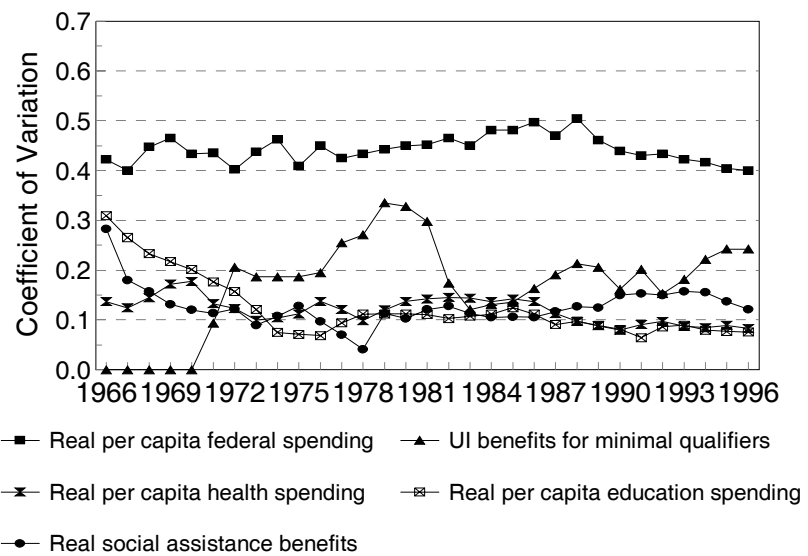

\section{Definitions: incomes and probabilities in the four employment states}

The three components of income that depend on the state of the world are defined as follows:

$$
\begin{gathered}
U I_{j s}=\left\{\begin{array}{lr}
0 & \text { if } s=1 \text { or } s=4 \\
\rho w_{j}^{R}\left(T-M X Y R_{j}-2\right) & \text { if } s=2 \\
\rho w_{j}^{R} M I N W K S_{j} & \text { if } s=3
\end{array}\right. \\
S A_{j s}= \begin{cases}0 & \text { if } s=1,2 \\
\frac{\overline{S A}_{j}}{52}\left(T-M I N_{j}-M I N W K S_{j}-2\right) & \text { if } s=3 \\
\overline{S A}_{j} & \text { if } s=4\end{cases} \\
B_{i s}= \begin{cases}0 & \text { if } s=4 \\
B_{i} & \text { otherwise },\end{cases}
\end{gathered}
$$


weeks of UI benefits that a person with $M I N$ weeks of work can receive, and $\overline{S A}$ represents annual social assistance benefits. The replaceable wage is computed using average weekly earnings in each province.

In equation (8), after-tax incomes net of moving costs in the four states of the world are denoted $I N C_{i j s}$ and, using the fact that $T=52$, may be written as:

$$
\begin{aligned}
& I N C_{i j 1}=50 w_{j}+B_{i}+T R_{i}-C_{i j}-T A X_{i j 1}, \\
& I N C_{i j 2}=w_{j} M X Y R_{j}+\rho w_{j}^{R}\left(50-M X Y R_{j}\right)+B_{i}+T R_{i}-C_{i j}-T A X_{i j 2}, \\
& I N C_{i j 3}=w_{j} M I N_{j}+\rho w_{j}^{R} M I N W K S_{j}+\frac{\overline{S A}_{j}}{52}\left(50-M I N_{j}-M I N W K S_{j}\right)+T R_{i}-C_{i j}-T A X_{i j 3}, \\
& I N C_{i j 4}=\overline{S A}_{j}+T R_{i}-C_{i j} .
\end{aligned}
$$

The two-week waiting period for UI benefits is taken into account in the calculation of incomes in states 2 and 3 . For all provinces except Quebec, provincial income taxes are computed as a percentage of federal income tax owing. In the case of Quebec, provincial income taxes were computed separately using the Quebec income tax schedule.

Letting $p_{20+}^{j}$ be the proportion of UI recipients with more than twenty qualifying weeks and $p_{<20}^{j}$ the proportion of UI recipients with less than twenty qualifying weeks, the ex ante probabilities of the four states of the worlds are approximated as:

$$
\begin{aligned}
& \pi_{j 1}=\frac{n_{E j}}{n_{E j}+n_{U I j}+n_{S A j}} \\
& \pi_{j 2}=\frac{p_{20+}^{j} \cdot n_{U I j}}{n_{E j}+n_{U I j}+n_{S A j}} \\
& \pi_{j 3}=\frac{p_{<20}^{j} \cdot n_{U I j}}{n_{E j}+n_{U I j}+n_{S A j}} \\
& \pi_{j 4}=\frac{n_{S A j}}{n_{E j}+n_{U I j}+n_{S A j}} .
\end{aligned}
$$

\section{The marginal effect of a change in MIN}

The derivative of $P_{i j}$ with respect to a change in $M I N$ in province $j$ is

$$
\frac{\partial P_{i j}}{\partial M I N_{j}}=P_{i j}\left(1-P_{i j}\right)\left\{\frac{\alpha_{1} \pi_{j_{3}}}{I N C_{i j 3}}\left[w_{j}\left(1-\tau_{i j 3}\right)-\frac{\overline{S A}_{j}}{52}\right]-\frac{\alpha_{2} \pi_{j 3}}{\left(T-M I N_{j}\right)}\right\} .
$$




\section{CESifo Working Paper Series}

(for full list see www.cesifo-group.de)

1545 Kjell Erik Lommerud, Frode Meland and Odd Rune Straume, Can Deunionization Lead to International Outsourcing?, September 2005

1546 Robert Inklaar, Richard Jong-A-Pin and Jakob de Haan, Trade and Business Cycle Synchronization in OECD Countries: A Re-examination, September 2005

1547 Randall K. Filer and Marjorie Honig, Endogenous Pensions and Retirement Behavior, September 2005

1548 M. Hashem Pesaran, Til Schuermann and Bjoern-Jakob Treutler, Global Business Cycles and Credit Risk, September 2005

1549 Ruediger Pethig, Nonlinear Production, Abatement, Pollution and Materials Balance Reconsidered, September 2005

1550 Antonis Adam and Thomas Moutos, Turkish Delight for Some, Cold Turkey for Others?: The Effects of the EU-Turkey Customs Union, September 2005

1551 Peter Birch Sørensen, Dual Income Taxation: Why and how?, September 2005

1552 Kurt R. Brekke, Robert Nuscheler and Odd Rune Straume, Gatekeeping in Health Care, September 2005

1553 Maarten Bosker, Steven Brakman, Harry Garretsen and Marc Schramm, Looking for Multiple Equilibria when Geography Matters: German City Growth and the WWII Shock, September 2005

1554 Paul W. J. de Bijl, Structural Separation and Access in Telecommunications Markets, September 2005

1555 Ueli Grob and Stefan C. Wolter, Demographic Change and Public Education Spending: A Conflict between Young and Old?, October 2005

1556 Alberto Alesina and Guido Tabellini, Why is Fiscal Policy often Procyclical?, October 2005

1557 Piotr Wdowinski, Financial Markets and Economic Growth in Poland: Simulations with an Econometric Model, October 2005

1558 Peter Egger, Mario Larch, Michael Pfaffermayr and Janette Walde, Small Sample Properties of Maximum Likelihood Versus Generalized Method of Moments Based Tests for Spatially Autocorrelated Errors, October 2005 
1559 Marie-Laure Breuillé and Robert J. Gary-Bobo, Sharing Budgetary Austerity under Free Mobility and Asymmetric Information: An Optimal Regulation Approach to Fiscal Federalism, October 2005

1560 Robert Dur and Amihai Glazer, Subsidizing Enjoyable Education, October 2005

1561 Carlo Altavilla and Paul De Grauwe, Non-Linearities in the Relation between the Exchange Rate and its Fundamentals, October 2005

1562 Josef Falkinger and Volker Grossmann, Distribution of Natural Resources, Entrepreneurship, and Economic Development: Growth Dynamics with Two Elites, October 2005

1563 Yu-Fu Chen and Michael Funke, Product Market Competition, Investment and Employment-Abundant versus Job-Poor Growth: A Real Options Perspective, October 2005

1564 Kai A. Konrad and Dan Kovenock, Equilibrium and Efficiency in the Tug-of-War, October 2005

1565 Joerg Breitung and M. Hashem Pesaran, Unit Roots and Cointegration in Panels, October 2005

1566 Steven Brakman, Harry Garretsen and Marc Schramm, Putting New Economic Geography to the Test: Free-ness of Trade and Agglomeration in the EU Regions, October 2005

1567 Robert Haveman, Karen Holden, Barbara Wolfe and Andrei Romanov, Assessing the Maintenance of Savings Sufficiency Over the First Decade of Retirement, October 2005

1568 Hans Fehr and Christian Habermann, Risk Sharing and Efficiency Implications of Progressive Pension Arrangements, October 2005

1569 Jovan Žamac, Pension Design when Fertility Fluctuates: The Role of Capital Mobility and Education Financing, October 2005

1570 Piotr Wdowinski and Aneta Zglinska-Pietrzak, The Warsaw Stock Exchange Index WIG: Modelling and Forecasting, October 2005

1571 J. Ignacio Conde-Ruiz, Vincenzo Galasso and Paola Profeta, Early Retirement and Social Security: A Long Term Perspective, October 2005

1572 Johannes Binswanger, Risk Management of Pension Systems from the Perspective of Loss Aversion, October 2005

1573 Geir B. Asheim, Wolfgang Buchholz, John M. Hartwick, Tapan Mitra and Cees Withagen, Constant Savings Rates and Quasi-Arithmetic Population Growth under Exhaustible Resource Constraints, October 2005 
1574 Christian Hagist, Norbert Klusen, Andreas Plate and Bernd Raffelhueschen, Social Health Insurance - the Major Driver of Unsustainable Fiscal Policy?, October 2005

1575 Roland Hodler and Kurt Schmidheiny, How Fiscal Decentralization Flattens Progressive Taxes, October 2005

1576 George W. Evans, Seppo Honkapohja and Noah Williams, Generalized Stochastic Gradient Learning, October 2005

1577 Torben M. Andersen, Social Security and Longevity, October 2005

1578 Kai A. Konrad and Stergios Skaperdas, The Market for Protection and the Origin of the State, October 2005

1579 Jan K. Brueckner and Stuart S. Rosenthal, Gentrification and Neighborhood Housing Cycles: Will America’s Future Downtowns be Rich?, October 2005

1580 Elke J. Jahn and Wolfgang Ochel, Contracting Out Temporary Help Services in Germany, November 2005

1581 Astri Muren and Sten Nyberg, Young Liberals and Old Conservatives - Inequality, Mobility and Redistribution, November 2005

1582 Volker Nitsch, State Visits and International Trade, November 2005

1583 Alessandra Casella, Thomas Palfrey and Raymond Riezman, Minorities and Storable Votes, November 2005

1584 Sascha O. Becker, Introducing Time-to-Educate in a Job Search Model, November 2005

1585 Christos Kotsogiannis and Robert Schwager, On the Incentives to Experiment in Federations, November 2005

1586 Søren Bo Nielsen, Pascalis Raimondos-Møller and Guttorm Schjelderup, Centralized vs. De-centralized Multinationals and Taxes, November 2005

1587 Jan-Egbert Sturm and Barry Williams, What Determines Differences in Foreign Bank Efficiency? Australian Evidence, November 2005

1588 Steven Brakman and Charles van Marrewijk, Transfers, Non-Traded Goods, and Unemployment: An Analysis of the Keynes - Ohlin Debate, November 2005

1589 Kazuo Ogawa, Elmer Sterken and Ichiro Tokutsu, Bank Control and the Number of Bank Relations of Japanese Firms, November 2005

1590 Bruno Parigi and Loriana Pelizzon, Diversification and Ownership Concentration, November 2005

1591 Claude Crampes, Carole Haritchabalet and Bruno Jullien, Advertising, Competition and Entry in Media Industries, November 2005 
1592 Johannes Becker and Clemens Fuest, Optimal Tax Policy when Firms are Internationally Mobile, November 2005

1593 Jim Malley, Apostolis Philippopoulos and Ulrich Woitek, Electoral Uncertainty, Fiscal Policy and Macroeconomic Fluctuations, November 2005

1594 Assar Lindbeck, Sustainable Social Spending, November 2005

1595 Hartmut Egger and Udo Kreickemeier, International Fragmentation: Boon or Bane for Domestic Employment?, November 2005

1596 Martin Werding, Survivor Benefits and the Gender Tax Gap in Public Pension Schemes: Observations from Germany, November 2005

1597 Petra Geraats, Transparency of Monetary Policy: Theory and Practice, November 2005

1598 Christian Dustman and Francesca Fabbri, Gender and Ethnicity - Married Immigrants in Britain, November 2005

1599 M. Hashem Pesaran and Martin Weale, Survey Expectations, November 2005

1600 Ansgar Belke, Frank Baumgaertner, Friedrich Schneider and Ralph Setzer, The Different Extent of Privatisation Proceeds in EU Countries: A Preliminary Explanation Using a Public Choice Approach, November 2005

1601 Jan K. Brueckner, Fiscal Federalism and Economic Growth, November 2005

1602 Steven Brakman, Harry Garretsen and Charles van Marrewijk, Cross-Border Mergers and Acquisitions: On Revealed Comparative Advantage and Merger Waves, November 2005

1603 Erkki Koskela and Rune Stenbacka, Product Market Competition, Profit Sharing and Equilibrium Unemployment, November 2005

1604 Lutz Hendricks, How Important is Discount Rate Heterogeneity for Wealth Inequality?, November 2005

1605 Kathleen M. Day and Stanley L. Winer, Policy-induced Internal Migration: An Empirical Investigation of the Canadian Case, November 2005 